University of Pennsylvania Carey Law School

Penn Law: Legal Scholarship Repository

Faculty Scholarship at Penn Law

1999

\title{
A Little Theory is a Dangerous Thing: The Myth of Adjudicative Retroactivity
}

Kermit Roosevelt III

University of Pennsylvania Carey Law School

Follow this and additional works at: https://scholarship.law.upenn.edu/faculty_scholarship

Part of the Conflict of Laws Commons, Constitutional Law Commons, Courts Commons, Jurisprudence Commons, Legal History Commons, and the Public Law and Legal Theory Commons

\section{Repository Citation}

Roosevelt, Kermit III, "A Little Theory is a Dangerous Thing: The Myth of Adjudicative Retroactivity" (1999). Faculty Scholarship at Penn Law. 801.

https://scholarship.law.upenn.edu/faculty_scholarship/801

This Article is brought to you for free and open access by Penn Law: Legal Scholarship Repository. It has been accepted for inclusion in Faculty Scholarship at Penn Law by an authorized administrator of Penn Law: Legal Scholarship Repository. For more information, please contact PennlawIR@law.upenn.edu. 


\title{
A Little Theory Is a Dangerous Thing: The Myth of Adjudicative Retroactivity
}

\author{
KERMIT ROOSEVELT III'
}

\section{INTRODUCTION}

The question of retroactivity is what to do when the law changes. More precisely, it is to whom the new law should be applied, and to whom the old. There are different answers to the question of differing degrees of plausibility. Some are quite old and others fairly new. But lurking behind the various instances of the question and its proposed solutions is a distinct intellectual difficulty, which I will call the problem of retroactivity. The question is a fairly narrow doctrinal issue: what rules should govern transitions between legal regimes? The problem is broader, and more jurisprudential. It is that the question has proved so hard to answer, that our jurisprudence has lurched from one solution to the next. This Article is not going to answer the question; it is going to solve the problem.

Law changes in two primary ways: via legislative and judicial action. Clearly a new statute changes the law. Legislative retroactivity has proved somewhat difficult to identify, but the rules that govern it are fairly well established. Legislation is presumptively treated as non-retroactive, but it may, subject to certain limitations imposed by the Ex Post Facto Clause, operate retroactively if the legislature so desires. ${ }^{2}$

* Senior Research Scholar, Yale Law School; Resident Fellow, Information Society Project. A. B. Hanard 1993: J.D. Yale 1997. I thank Beth Apsel. Chris Kutz, and Stephen F. Williams for helpful advice and comments. Bruce Ackerman deserves special gratitude for contributions to both the drticle and its subject matter. Faults are mine.

1. The difficulty lies in identifying, or stipulating, what counts as a "retroactive" effect. Courts have distinguished between "primary" and "secondary" retroactivity, of which the former alters the past legal effect of past conduct, and the latter only the future legal effect of past conduct. See Bowen v. Georgetown Univ. Hosp., 488 U.S. 204, 220 (1988) (Scalis, J., concurring). Commentators have attacked the entire concept of retroactive effect as inherently confused. See, e.g, Jill E. Fisch, Retroactivity and Legal Change: An Equilibrium Approach, I10 HARV. L. REV. 1055, 1069 (1997); see generally Stephen R. Munzer, Retroactive Law, 6 J. LEGAL. STUD, 373, 374-81 (1977) (discussing the tauits and strengths of various theories of retroactive law).

2 See Landgraf v U.S.L Film Prods., 511 U.S. 244 (1994). A competing line of cases, now disfavored, applied new statutory law to actions predating the enactment of the statute. See Bradley v. 
Judicial retroactivity is far more complicated. Judicial decisions operate on several different kinds of law: common law, statutes, and the Constitution. The differing positive sources of the law being changed impart a different character to each type of decision. At one end of the spectrum lie judicial interpretations of statutes. The judicial decisions are evidence of what the law is, but they are not, except in a purely predictive sense, the law. The law is the statute; take it away, and the judicial decisions lose their force. Since an unchanging ${ }^{3}$ statute backs the judicial interpretations, it makes sense to say that while decisions may change, the law remains the same. An overruled decision is simply wrong; it is not and was never the law. Consequently, retroactivity in statutory interpretation is not very difficult. The new, correct decision is applied to everyone. ${ }^{4}$

At the other end of the spectrum is the common law. Once it was believed that the common law had a positive source independent of judicial decisions, but this view has no modern adherents. Instead, it is now recognized that the positive source of the common law is just the judicial decisions in which it is embodied. With no positive source independent of judicial decisions, the law must change as the decisions change. Consequently, it makes sense to distinguish between old law and new law. When law changes, there is a real question as to when it does so, and there are real questions about to whom the new law should be applied.

Occupying the middle ground, and serving as the focus for this Article, is constitutional law. An analysis that works in terms of positive source is difficult, since the origin of constitutional law proves surprisingly hard to identify Constitutional law has a positive source-the hallowed document-independent of judicial decisions. But the view that the Constitution means now what it always has, and always will, has serious difficulties. This is not to say that it does not have redoubtable defenders, ${ }^{5}$ nor that, as a normative theory of interpretation, it is unattractive. The

School Bd. of Richmond, 416 U.S. 696, 711 (1974); Thorpe v. Housing Auth. of Durham, 393 U.S. 268, 281 (1969); United States v. The Schooner Peggy, 5 U.S. (1 Cranch) 103 (1801). Landgraf made a heroic, although not entirely convincing, attempt to rationalize the treatment of retroactive legislation without abandoning these cases. See Landgraf, 511 U.S. at 273-79.

3. While statutes are obviously unchanging from a certain perspective (if not amended, their words remain constant), they may actually direct different results at different times as the surrounding legal context changes. For instance, a statute that conditions on a conviction for a crime "of moral turpitude" might well have been triggered by a broader range of conduct in 1850 than it would be today.

4. See Lampf, Pleva, Lipkind, Prupis \& Petigrow v. Gilbertson, 501 U.S. 350 (1991); cf. Davis y. United States, 417 U.S. 333, 346-47 (1974) (holding that collateral relief is available if a new decision establishes that a prisoner was convicted "for an act that the law does not make criminal").

5. For example, Supreme Court Justice Antonin Scalia. See, e.g., American Trucking Ass'ns v. Smith, 496 U.S. 167, 201 (1989) (Scalia, J., concurring) (stating that "the Constitution does not change from year to year"). 
difficulty is rather that it is hard to keep a straight face while suggesting that the current panoply of substantive and procedural rights has always existed, or, to take a less controversial example, that the First Amendment has always embodied its current congeries of doctrines and distinctions. ${ }^{6}$ The idea of an unchanging Constitution, as a descriptive matter, is a poor fit with the realities of doctrinal evolution. Functionally, constitutional law more closely resembles common law than statutory interpretation.

These types of law lie, as I have been saying, along a spectrum. Some statutes have gaps, like the meaning of "restraint of trade" in the Sherman Act, ${ }^{7}$ that are large enough that courts filling them in are essentially engaging in common lawmaking. ${ }^{8}$ But there is no principled difference between gap-filling and interpretation. An approach to the question of retroactivity based on positive source, then, can explain judicial behavior in some cases, but it will not help to decide the hard questions. Nor, as will be seen later, is this type of metaphysical analysis especially useful in resolving the practical difficulties raised by adjudicative retroactivity.

In fact, there may be no analysis that satisfactorily answers the question of retroactivity. This is because the question has been posed in the wrong way, lodged in an analytic framework that sets up insuperable difficulties. The purpose of this Article is to shatter that framework and in so doing to dissolve the difficulties, but shattering and dissolution are a ways down the road. The first task, the concern of Part II, is to articulate the question as it has been posed and to examine the attempts of the Supreme Court and its academic auxiliaries to answer it. Part III then attempts to reveal the conceptual apparatus that drives us to that way of posing it, and to propose an alternative way of thinking.

Though it pauses at times to engage in theoretical analysis, this Article at heart tells a story. Stripped to its essentials, the story chronicles four different legal regimes. First, in the old days of the common law, judicial lawmaking was understood as law-finding. ${ }^{9}$ Following the lead of William Blackstone, judges conceived of the common law as existing independent of judicial decisions, a timeless constant that judges struggled to discern. To put it in terms of the discussion above, all judicial lawmaking partook of the theoretical structure of statutory interpretation, and when later judicial decisions reached results incompatible with earlier ones, this was not viewed as a change in the law. Consequently, questions of retro-

6. For an insightful analysis of the evolution of First Amendment doctrine, see David Yassky, Eras of the First Amendment, 91 COLUM. L. REV. 1699 (1991).

7. 15 U.S.C. $\$ 1$ (1994).

8. But cf Richard A, POSNer. THE Problems of JuRISPRUdence 289 (1990) (rebutting the view that the Sherman Act delegates common law authority to courts).

9. See infra Part II:A.1. 
activity were easy, indeed, invisible. New judicial rules, seen as more accurate statements of the law, were applied to the parties before the court regardless of when the transaction being litigated took place. Because the law itself did not change, there was no sense in which the decisions operated retroactively.

The second era ${ }^{10}$ opened with the Supreme Court's decision in Erie Railroad Co. v. Tompkins. ${ }^{11}$ Erie rejected the idea that judicial decisions were merely evidence of an unchanging common law; instead, it recognized that the common law was nothing more than those decisions. Consequently, a decision reaching a new result made new law, and the question of retroactivity appeared for the first time: Should the new law be applied to transactions that took place before the date of the law-changing decision? During this second era, courts answered the question affirmatively, basing decisions on the law in force at the time the decisions were rendered, regardless of what the law might have been at the time of the transaction being litigated. This practice has some intuitive appeal. A new rule will presumably be adopted because it is thought superior to the old one, and the reasons why it is superior will often-though not always - apply to the parties before the court. ${ }^{12}$ The jurisprudence of this second regime reflects an awareness of retroactivity and of prospectivity (the technique of applying new rules only to cases arising after the new rules are announced). ${ }^{13}$ But because the general approach was still for courts to apply the law in effect at the time they rendered decisions, there was no need to ask whether a decision operated retroactively in the sense of changing what the law was in the past.

This approach, which I will call "the decision-time model" was the hallmark of the second regime. The third era starts with the Warren Court's decision in Linkletter $v$. Walker, ${ }^{4}$ and it marks a radical break from the past in terms of both the results reached and, more significantly, the analytical approach. ${ }^{15}$ Linkletter abandoned the second regime's principle that courts should apply the law in effect at the time they render their decisions. Instead, it started from the premise that parties should be gov-

10. See infra Part II.A.2.

11. 304 U.S. 64 (1938).

12. If the new rule is thought substantiveiy more fair (because. for example, it imposes the "coirect" standard of care on a landowner), the value of fairness will usually be promoted by applying the new rule to the parties before the court. If the new rule is thought better because it increases predictability, however, the value of predictability will seldom be served by application to parties who expected their conduct to be governed by a different rule.

13. See infra Part II.A.2.

14. 381 U.S. 618 (1965).

15. See infra Part II A.3. 
erned by the law in effect at the time of their actions. ${ }^{16}$ This premise is the hallmark of what I will call "the transaction-time model." This approach made it easier to employ prospectivity, which was undoubtedly a main purpose of the theoretical switch. However, it complicated the effort to obtain the results that formerly were reached simply by applying current law: ${ }^{17}$ For if the result dictated by current law is to be reached despite the fact that the appropriate law is the law in effect at the time of the transaction, the law-changing decision must reach back in time to change what the law was. The Warren Court's switch from the decision-time to the transaction-time model is the birth of modern retroactivity jurisprudence.

The fourth regime ${ }^{18}$ is the history of attempts to cope with the Warren Court's legacy. As later sections will show, the transaction-time model bequeathed us by the Warren Court is prey to insuperable theoretical difficulties. Modern jurisprudence has with great difficulty made its way back to the principle that new law should generally govern parties regardless of when the transaction being litigated took place. But it has done so within the transaction-time model; it has done so by asserting that ever-broader categories of decisions are to be applied retroactively. Consequently, it has not freed itself from the difficulties that attended the Warren Court's jurisprudence, and the current law of retroactivity is widely regarded as intellectually unsatisfactory. This is terribly ironic, for what has happened is that the concept of retroactivity has assumed greater prominence as part of an attempt to solve a problem that was created by the introduction of that very concept.

This Article was inspired by the recognition of that irony, but it does not aim simply to point out the humor in our predicament. It offers the possibility of solving the problem of retroactivity by returning to the jurisprudence of the second regime. This is a simple point, but a convincing presentation of it requires not only recounting the history of retroactivity jurisprudence but also developing an appropriate perspective from which to view it. Without the theory, the story is all but pointless; without the story, the theory is numbingly abstruse and esoteric. The Article tries to weave the two together, but even this introduction is no doubt rendered a bit cryptic by the lack of theoretical ground-laying. The next section thus undertakes a necessary exposition of the analytical framework and introduces a bit of useful vocabulary; then, the real story will begin.

16. See infra notes 209-13 and accompanying text.

17. See infra Part III.A.1.

18. See infra Part II B. 


\section{THE QUESTION OF RETROACTIVITY}

Consider a transaction between two parties occurring at Time $l$ and a lawsuit filed immediately thereafter. Under the settled law at Time 1 , Party $A$ will prevail (the "transaction-time result"). At Time 2, the Supreme Court hands down a law-changing decision; under the new law, Party $B$ will prevail (the "decision-time result"). ${ }^{19}$ At Time 3 , the lawsuit comes before the Court. ${ }^{20}$

It is clear that there are two possible outcomes. Either Party $A$ wins, or Party $B$ does: The Court will reach either the transaction-time or the decision-time result. What determines the outcome? Although the Court has recently characterized the issue as one of temporal "choice of laws," the actual analysis it performs bears no obvious resemblance to any currently popular approach to choice of law..$^{22}$ It starts from the premise that parties should be judged by the law in effect at the time of their actions ("transaction-time law"). ${ }^{23}$ The question is thus not what law is to be applied but rather what the transaction-time law is. If the decision-time result is to be reached, it must be because decision-time law has become

19. The question of whether the court applies the new rule to the parties before it in the Time 2 case is certainly relevant, and at times has been held dispositive. See, e.g. Harper v. Virginia Dep tof Taxation, 509 U.S. 86, 97.99 (1993). Other cases have given it no weight. See, e.g. Stovall v. Denno, 388 U.S. 293, 300-02 (1967). This issue will feature prominently later; in the interests of smooth exposition, I postpone the discussion.

20, I postpone consideration of the further complication of whether the case is presented on direct or collateral review.

21. James B. Beam Distilling Co. v. Georgia, 501 U.S. 529, 535 (1991).

22. Earlier retroactivity analysis inquired whether the purpose of the new rule would be served by its application in the case before the Court. See, e.g., Chevron Oil Co. v. Huson, 404 U.S 97,106 (1971): Linkletter $v$ Walker, 381 U.S, 618, 628 (1965). This bears some similarity to Brainerd Curtie's governmental interest analysis of choice-of-law questions. See generally LEA BRILMAYER, CONFLICT OF LAWS $47-59$ (1995). The current approach, focusing on rights parties hold at the time of their actions, resembles most closely the "vested rights" theory championed by Joseph Beale and popular in the early twentieth century. See id at 20-25. Beale's approach is now thoroughly discredited, see id at 25-41, which makes it a less than encouraging starting point for modern retroactivity jurisprudence.

23. This principle is not self-evident (indeed, I will argue later that it is wrong), but it has strong intuitive appeal, particularly in the criminal context. See, e,g. RONALD DWORKIN, TAKING RJGHTS SERIOUSLY 85 (rev. ed. 1978) ("We all agree that it would be wrong to sacrifice the rights of an innocent man in the name of some new duty created after the event."). The Supreme Court also adopts it. See, e.g., Stovall, 388 U.S. at 296 (focusing on the date of conduct). So, too, did Joseph Beale; indeed, the principle that judges do no more than declare rights that vested at the time of the relevant transaction was central to his conflicts theory. See, e.g, I JOSEPH BEALE, CONFLICT OF LAws 38 (1935) ("II]f the judge makes the laty he declares, then the law did not exist at the commission of the alleged wrong .... and the defendant is held for a wrong which was not a wrong at the time he did it. This is contrary to all conceptions of justice."). Beale, unlike Dworkin and the Supreme Court, relied on Swift v. Tyson. 4 I U.S. (16 Pet) 1 (1842) for this claim. See id. at 39 ("[A] difference of opinion between the state court and the federal court sitting in the state as to the law of the state... is quite incompatible with the court making the law.") 
transaction-time law, i.e., because the new law is effective retroactively. ${ }^{24}$

The Court thus has two options. It may apply the Time 2 decision retroactively, thereby changing the law in effect at Time 1 . This approach reaches the decision-time result although nominally applying transactiontime law: Party $B$ wins. ${ }^{25}$. The second possible technique is to announce that the Time 2 decision is to have only prospective effect. The new rule will apply only to cases filed after the date of the Time 2 decision. The law changes at Time $2,{ }^{26}$ but the "old" Time 1 law will govern cases filed before then: Party $A$ wins. ${ }^{27}$

This model of retroactivity analysis is what I have called the "transaction-time model," One of its consequences, which will turn out to be an Achilles heel of sorts, bears mentioning. Suppose the Court reaches the first of the two above dispositions and applies the Time 2 decision retroactively. This approach changes the law in effect at Time $I$. The result is that a case finally decided between Time 1 and Time 2 is rendered incorrect. The retroactive application of new law injects error into proceedings that were error-free when conducted.

This consequence is a significant source of the difficulties attending the question of retroactivity. The question itself, however, is simply phrased: How should the Court make the decision between prospective and retroactive application? It is a hard question, and it has inspired much clever and innovative scholarship. More importantly, it is the wrong question. It is a question that cannot be answered and that never should have been asked. It exists, I will argue, only because of the Warren Court's misunderstanding of earlier decisions, and it implies a theoretical framework that is unworkable in principle and in practice.

\section{A. The Historical Origins of Retroactivity: The Question Raised}

The question of retroactivity seems one of obvious importance. Whatever we think of Holmes ${ }^{2}$ famous dictum, ${ }^{28}$ the life of the common law has certainly been change. Changes in judge-made law demand that the courts oversee transition between the legal regimes. It might be expected, then, that at common law there would be at least some recognition of the diffi-

24. To a certain extent, this idea of a faimess-based requirement of transaction-time law has been constitutionalized as a prohibition on ex post facto legislation. See U.S. ConsT. art. I, \$\$ 9, 10.

25. For an example of this approach. sce Griffith v. Kentucky, 479 U.S. 314, 328 (1987).

26. Consistency with the Court's commitnent to transaction-lime law would require that the law change at the time of the transaction. giving rise to the Time 2 lawsuit. The Court has, however. always treated the date of the decision as dispositive. See Linkletter v. Walker, 381 U.S 618, 639 (1965).

27. For an example of this approach. see Chevron Oil Co. v. Huson, 404 U.S. 97. I05-09 (1971).

28. Oliver Wendell HOLMES, JR., THE COMMON LAw 1 (1881) ("The life of the law has not been logic, it has been experience.") 
cult issues created by adjudicative retroactivity. Significantly, this is not so. The case most often cited as the first example of retroactivity jurisprudence, United States $v$. The Schooner Peggy, ${ }^{29}$ features legislative, not adjudicative, retroactivity, and it disposes of the issue with the truism that a court must apply the law in effect at the time it renders its decision. (The law at issue in The Schooner Peggy specified that it was to have retroactive effect, and the Court applied it. Modern courts, in exempting preenactment transactions from the scope of statutes that do not so specify, are of course also applying the law in effect at the time of their decisions; the law is interpreted not to reach those transactions.)

Before the Warren Court, the question of retroactivity was not found in the case law, for the simple reason that the concept of retroactivity was not there either. As the following sections discuss, the concept had no application according to the dominant nineteenth-century understanding of the common law. A functional retroactivity-analytically quite distinct from the current version-arose as that understanding eroded, and it was this idea that was appropriated by the Warren Court and pressed into service for a task to which it was not suited.

\section{The Blackstonian Model}

The concept of retroactivity is a relative newcomer to our jurisprudence. In 1910, Justice Holmes could write, "Judicial decisions have had retrospective operation for near a thousand years." Who Holmes was right in terms of result, his description was theoretically slightly off. The nineteenth century's received understanding of the judicial role was encapsulated in Blackstone's adage that judges are "not delegated to pronounce a new law, but to maintain and expound the old one." declaratory theory, judicial common law decisions reflected, but did not embody, the law. The result of this conception of law was that a change in a court's ruling implied "not that the law is changed, but that it was always the same as expounded by the later decision, and that the former decision was not, and never had been, the law, and is overruled for that very reason." $" 32$

This understanding of the nature of law will, of course, produce the uniformly retroactive result to which Holmes adverted. That result is not,

\footnotetext{
29. 5 U.S. (1 Cranch) 103 (1801).

30. Kuhn v Fairmont Coal Co., 215 U.S. 349, 372 (1910) (Holmes, J. dissenting).

31. I WILLIAM BLACKSTONE, COMMENTARIES *69-70 (1765-69).

32. Gelpcke v City of Dubuque, 68 U.S. (I Wall.) 175.211 (1863) (Miller, J, dissenting). See Harry Shulman, Retroachive Legislation, 13 ENCYCLOPEDIA OF THE SOCIAL. SCIENCES 355, 356 (Alvin Johnson \& Edwin R.A. Seligman eds., 1934) (describing overruling decisions as not "new law but an application of what is, and theretofore had been, the true law").
} 
however, correctly characterized as retrospective application of changed law. Instead, the Blackstonian model takes law as a timeless constant, always (optimistically) assuming the correctness of the current decision. Prior inconsistent decisions are and always were incorrect. ${ }^{33}$ The consequence of this idea of law as an apotheosized immutable is that the concept of retroactivity has no place; "old law" and "new law" are necessarily the same.

Changes in law could occur via legislation, of course, and this at least provided a chance for the question of retroactivity to raise its head, Doctrinally, however, prospectivity was not even nascent; the concept of retroactivity was simply not discussed. ${ }^{34}$ In the 1801 case of The Schooner Peggy, Justice Marshall had stated flatly that "if subsequent to the judgment and before the decision of an appellate court, a law intervenes and positively changes the rule which governs, the law must be obeyed, or its obligation denied." The Schooner Peggy dealt with the effect of legislative changes. The treaty at issue specified that it was to have retroactive effect and presumably, Marshall would similarly have followed a law dictating that it was to be applied only to post-enactment transactions. The Schooner Peggy simply instructs courts to apply the law in effect at the time of their decisions, and this principle had no serious challengers until the twentieth century. ${ }^{36}$

\section{Intimations of Prospectivity}

The Blackstonian model, in its full metaphysical glory, is something of a legal unicorn. Its transcendently brooding common law does not exist now, and never really did, although it there are still rare reported sightings $^{37}$ and sideshow simulacra. ${ }^{38}$ It is acceptable within a unified ju-

33. The difference between a Blackstonian model and retroactive application of new law is that retroactive application changes the law (and does so only so far back as the decision is applied retroactively). This is a fine distinction. and unpleasantly metaphysical, but such are the consequences of the Blackstonian account

34. See Linkletter v. Walker, 381 U,S $618,622-24$ (1965)

35. United States v. The Schooner Peggy, 5 U.S. (1 Cranch) 103, 111 (1801)

36. Some early cases seem to truat legislation as presumptively non-retroactive, creating a tension with the Bradley-Thorpe line of cases discussed supra note 2. See Chicago. Indianapolis, \& Louisyille Ry. Co. v. Hackett, 228 U.S. 559, 567 (1913) (refusing to address question of possible preemption of state statute by post-transaction federal legislation). However, as an interpretive presumption, this approach does not really conflict with The Schooner Peggy's admonition to apply the law in effect at the time of the decision; it simply suggests that, absent evidence to the contrary. the law will be read as though it directed courts not to apply it to pre-enactment transactions.

37. In particular. Blackstonian visions periodically visit Justice Scalia. See supra note 5: see also ANTONIN SCALIA, A MATTER of INTERPRETATION 40 (1997). Of coursc. Justice Scalia is not a Blackstonian with respect to common law, and it is only the pervasive willingness to bring a comimon law perspective to constitutional interpretation that makes his originalism in that endeavor appeaf Blackstonian 
dicial system, but the existence of two sets of independent tribunals expounding the same law tests it severely.

Such was the case with respect to the concurrent jurisdiction of state and federal courts under Swift v. Tyson ${ }^{39}$ in the nineteenth and early twentieth centuries. ${ }^{\text {to }}$ While federal courts deferred to state courts on matters of statutory interpretation, "where private rights are to be determined by the application of common law rules alone, [the Supreme Court], although entertaining for state tribunals the highest respect, does not feel bound by their decisions." "4) Swift sounded a Blackstonian theme, stating that decisions of courts "are, at most, evidence of what the laws are and are not, of themselves, laws," and went on to affirm that state court decisions "cannot furnish positive rules, or conclusive authority, by which our own judgments are to be bound up and governed. ${ }^{143}$ The existence of distinct and overlapping state and federal common law created obvious difficulties for parties structuring transactions, but it followed from the idea of a transcendent common law of which judicial decisions were only reflections.

The fact that settled state court constructions of state statutes were authoritative made things easier for private parties but somewhat more difficult for metaphysicians. The binding effect of settled state court interpretations made them functionally quite similar to "real" law, but a Blackstonian federal judge might still believe that state court decisions were, in some sense, wrong. It was in this context that portents of the question of retroactivity first appeared. ${ }^{44}$

In a series of cases dealing with defaults on municipal bonds, the Court declined to follow post-transaction state court decisions on state

38. Ronald Dworkin, as discussed infra text accompanying notes 171-81, embraces a Blackstonian account as part of his attempt to distinguish himself from positivists. Unlike Justice Sealia, he does extend this approach to common law.

39. 41 U.S. (16 Pet.) 1 (1842).

40. Formally, the regime discussed below survived until Erie Railroad Co. v Tompkins. 304 U.S 64 (1938). However, the doctrine was moribund substantially earlier. See Kuhn y. Fairmont Coal Co.. 215 U.S. 349, 371 (1910) (Holmes, J., dissenting).

41. Chicago v Robbins, 67 U.S. (2 Black) 418,428-29 (1862).

42. Swift, 41 U.S. a: 5. It may be useful at this point to distinguish between two senses of the "made" vs, "found" distinction. In one sense, as a realist/Blackstonian debate, the question is whether law exists independent of judicial decisions. It is in this sense that Sivift denies that judges make law. and endorses a position that has almost no modern adherents. See Richard H. Fallon, Jr. \& Danicl J Melizer. New Law, Non-Retroactivity, and Constitutional Remedies, 104 HARV. I. REV. 1731, 1759 (1991) In the other sense, a natural law/positivism debate, both sides accept that judicial decisions are law; the question is the degree of constraint on the decisionmaking process. If the first debate is dead, the second is deadly; this Article will avoid it as misguided, inconclusive, and unproductive.

43. Swift, 41 U.S. at 19 .

44. Portents only. As 1 argue below, the following cases feature spurious non-retroactivity, functionally identieal to the real thing but anaiytically distinct 
statutory issues. Gelpcke v. Dubuque, ${ }^{\text {is }}$ the first in the series, is illustrative. In 1857, the city of Dubuque issued bonds in support of two local railroads. ${ }^{46}$ Between 1853 and 1859 , the Iowa Supreme Court repeatedly upheld the statute authorizing the issuance against challenges under the Iowa Constitution. ${ }^{47}$ In 1859 , however, it reversed itself.

That settled the issue, presumably, for the lowa courts: the statute was unconstitutional $\mathrm{ab}$ initio and the bonds were no good. But what of the overlapping system of federal jurisdiction? How should federal courts treat the constitutionality of the statute with respect to bonds (like Dubuque's) issued before the lowa court's reversal?

If a question can be imagined, it will usually be litigated, and this one proved no exception. Bondholders sued Dubuque in federal court for failing to pay coupons on the 1857 bonds. The city defended on the grounds that the statute was unconstitutional and the issuance of the bonds ultra vires and void. ${ }^{48}$ The question for the Supreme Court was whether it was bound by a state supreme court decision handed down after the relevant transaction. ${ }^{49}$

The Court answered no. Since federal courts were ordinarily bound by state court statutory interpretations, the effect of the Gelpcke decision was to refuse retroactive effect to the Iowa Supreme Court's holding of unconstitutionality. Burgess v. Seligman ${ }^{50}$ and Kuhn v. Fairmont Coal Co. ${ }^{51}$ similarly refused to be bound by post-transaction state supreme court decisions. Both Burgess and Kuhn, however, featured questions of state law unsettled at the time of the transaction rather than state court reversals.

We might read these decisions as working within the transaction-time model set out above and denying retroactive effect to a change in law. Justice Holmes' dissent in Kuhn took precisely this perspective, arguing that the "fiction" of Swift v. Tyson" had been abandoned, that "decisions of state courts of last resort make law for the state," and hence that "a change of judicial decision after a contract has been made on the faith of an earlier one the other way is a change of the law." Holmes characterized Gelpcke and other municipal bond cases as resting "not on the

\footnotetext{
45. 68 U.S ( 1 Wall.) 175 (1863)

46. See id at $177-78$.

47. See id. at 179-87.

48. See id at 179 .

49. See id at $179-80$.

50. 107 U.S $20(1883)$

51. 215 U.S. 349 (1910). At issue in Kuhn was not statutory interpretation but common law. The Court, however, conceded that a setted pattern of state court decisions of the issuc would create a "rule of property" with the binding effect of statutory interpretations. See id. at 360 .

52. 4 I U.S. (16 Pet.) 1 (1842), overruled by Eric R. R. Co. V. Tompkins, 304 U.S. 64 (1938).

53. Id. at 371 (Holmes, 3 dissenting).
} 
grounds that this court agreed with the first decision, but on the ground that the state decision made law for the state, and therefore should be given only a prospective operation when contracts had been entered into under the law as earlier declared." " 44 Because Kuhn dealt with unsettled law, Holmes argued that the state court decision should be authoritative and retroactive. "I know of no authority in this court to say that, in general, state court decisions shall make law only for the future." 55

Holmes, as usual, was slightly ahead of his time. Although he had only to wait for the assertion of that authority, it was not being exercised by his colleagues. The Gelpcke Court wavers in its characterization of its reasoning. In some places it suggests that it refuses to follow the latest Iowa decision because it should be prospective: "However we may regard the late case in Iowa as affecting the future, it can have no effect upon the past." ${ }^{156}$ In others it suggests that the later decision is wrong: "The earlier decisions, we think, are sustained by reason and authority." Burgess and Kuhn are somewhat clearer. Those Courts refuse to be bound by intervening state decisions not because the decisions are prospective only but because they are not authoritative, and the decisions are not authoritative because of the independence of the federal judiciary from state decisions not representing settled rules. ${ }^{58}$ This independence relies on the Swift idea that decisions are not law but merely evidence of it. In Burgess, notably, the state court decisions arose out of the same transaction being litigated in federal court; the state courts had thus declared the law governing that very transaction. ${ }^{59}$ The Court's decision was driven by its understanding

54. Id

55. Id. at 372 .

56. Gelpcke v. Dubuque, 68 U,S. (I Wall.) 175, 206 (1863). If we take this remark to be referring to the effect of the decision on what the law was, then it sounds like an assertion of prospectivity if we understano it as referring to what the federal court is bound by. it fits more neatly within a Blackstonian model. The latter is the better reading, the Court claims that while the lowa interpretation might in the future become authoritative over federal courts (by attaining, through repetition, the status of settled adjudication), it is not now Interestingly, Justice Scalia, whe merits the tepidly contested distinction of being the greatest living constitutional Blackstonian. wis to echo the Gelpcke Court in his concurrence in American Trucking Iss'ns is Smith, 496 U.S, 167, 202-04 (1990) (Scalia, J., concurring). See infra notes 155-57 and accompanying text. Justice $0^{\circ} \mathrm{Connor}$. who does not rival him in this respect, tried a similar tack with less success in James B. Beam Distilling Co v, Georgia, 501 U.S. 529, 550-52 (1991) (O'Connor. J., dissenting). See infra note 271

57. Gelpcke is a mutufaceted case with constitutional overtones; arguabiy, following the last lowa cour decision and voiding the bonds would have violated the federal constitution by impairing contracts valid when formed. (There is. of colirse. the facile response that if the decision is retroactive, the contracts were not valid when formed, an argument that has succeeded at least once See Tidal Oil Co. v. Flanagan, 263 U.S. 444 (1924)).

58. See Burgess v. Seligman, 107 U, S, 20, 32-34 (1883).

59. See id at 35 . The image of federal courts ignoring the pronouncements of state courts as to state law governing the precise transactions being litigated in federal court is striking. The proof that those who do not learn from history are doomed to repeat it came when the same scene was re-enacted 
not of "old law" or "new law," but of "true law," The question it sought to answer was not "What was the governing law at the time of this transaction?" but simply "What is the governing law?"

The fact that federal courts were bound only by settled state court decisional rules allowed for functional prospectivity. Until a state court's changed interpretation represented a settled rule, federal courts could disregard it, even for post-decision transactions. But the issue was clearly one of authority, not of retroactivity, ${ }^{61}$ It was not until fifty years later that Burgess, Kuhn, and Gelpcke would be seen through the lens of retroactivity jurisprudence- and then they would not be seen well.

\section{The Birth of (Non)retroactivity: The Warren Court's Mistake}

The strong Blackstonian position of Swift v. Tyson, that judicial decisions were merely evidence of an independent and unchanging common law, appears implausible to the modern eye. It was not much more popular with even its near contemporaries. ${ }^{62}$ With the recognition that courts make law came the possibility of prospective overruling. Academics had begun to discuss the idea by the turn of the century, ${ }^{63}$ and in the 1932 case of Great Northern Railway Co. v. Sumburst Oil \& Refining Ca, the Supreme Court approved the practice as constitutionally legitimate in state

within the federal judicial system under Stovall v, Denno, 388 U.S. 293 (1967). See infra notes 91-93 and accompanying text.

60. See Vandenbark v. Owens-Illinois Glass Co., 311 U.S. 538, 540-41 \& nn.9-10 (1941) (describing Burgess and Kuhn as relying on federal independence rather than non-retroactivity)

61. Indeed, Gelpcke's most memorable lines are a ringing, if overheated, affirmation of federal independence: "We shall never immolate truth, justice, and the law because a State tribunal has erected the altar and decreed the sacrifice." Gelpcke, 68 U.S. at 206-07.

62. See, e.g. W. J. Adams, Jr. Constitutional Law-Protection of Rights Acquired in Reliance on Overruled Decision, II N.C. L. REV. 323, 329 (1933) (characterizing the Blackstonian account as "antiquated dogma and useless fiction"); Charies E. Carpenter, Decisions and the Common Law, 17 COLUM L. REY. 593 (1917) (arguing that courts make law). The Carpenter article is interesting as an early example of the transaction-time model. Carpenter argues for the prineiple that parties should be governed by the law in effect at the time of their actions, which he identifies with the doctrine that courts make law. See id, at 604 ("If the decisions of the courts make the law, the over-ruling decision need have no retroactive operation beyond that involved in the decision itself, because the over-ruling decision merely changes the law from the time it is made and leaves the law prior to that time unchanged") But this is a too-facile assimilation of judicial to legislative changes in law. For one thing, it takes the apparently incoherent position (later adopted by the Supreme Coun in Limkletter p. Walker, 381 U.S. 618,639 (1965)) that applying transaction-time law requires the court to look to the latest decision issued at the time of the transaction. The obvious problem with this procedure is that if the law-changing decision is applying transaction-time law (retroactively altered or not), the changed law is held effective as of the date of that transaction. Thus, the relevant dates are dates of transactions, not decisions.

63. See Beryl Levy, Realist Jurisprudence and Prospective Overndling, 109 U. PA. L. REV. 1, 7-8 (1960) (attributing the first scholarly endorsement of prospective overruling to a 1917 specch by George F. Canfield and noting that state courts had employed the technique even as early as the fatenineteenth century). 
courts. ${ }^{64}$ Characterizing the Blackstonian account as "ancient dogma," Justice Cardozo wrote, "A state in defining the limits of adherence to precedent may make a choice for itself between the principle of forward operation and that of relation back. It may say that decisions of its highest court, though later overruled, are law nonetheless for intermediate transactions." 65

Well before Erie, in other words, the spirit of the law had begun to slip into the body of judicial decisions. With the Erie decision, Swift v. Tyson was explicitly overruled and the incarnation was complete. The common law thus descended from the heavens was plainly mortal. As courts overruled themselves, law could change; law could die. With the possibility of law-changing decisions, the false unity of the Blackstonian model dissolved. Transaction-time and decision-time law became recognizable as clearly distinct entities.

Because the practice under the Blackstonian understanding was to give automatic effect to later statements of the law, the principle of simply applying decision-time law had a significant advantage. Already enshrined in Marshall's The Schooner Peggy opinion, it quickly extended its reach to law-changing decisions. If the operative rule is simply to apply current law, the concept of retroactivity has no role to play, and Supreme Court decisions through the 1940s, relying heavily on The Schooner Peggy, applied decision-time law without discussion in cases where changes were wrought by intervening legislation ${ }^{60}$ or decisions. ${ }^{67}$ Vandenbark v. OwensIllinois Glass Co ${ }^{68}$ explicitly repudiated Burgess and Kuhn, holding that federal courts "should conform their orders to the state law as of the time of the entry. Intervening and conflicting decisions will thus cause the reversal of judgments which were correct when entered." ${ }^{969}$ Vandenbark clearly follows The Schooner Peggy in dictating that current law be applied. Like The Schooner Peggy, however, it holds out the possibility of

64. 287 US. 358 (1932). It has been argued that Sumburst does not speak to prospectivity of constitutional decisions. See James B. Haddad, The Finality Distinction in Supreme Court Retroactivity Analysis: in Inadequate Surrogate for Modificalion of the Scope of Federal Habeas Corpus, 79 NW. U. L. REV, 1062, 1065-66 (1984). Levy suggests that Cardozo's interest in prospectivity stemmed from a retroactive increase in course requirements that Columbia Law School had imposed while Cardozo was a student, Refusing to submit, he never received a law degree. See Levy, supra note 63 , at $10 \mathrm{n} .31$

65. Sumburst, 287 U.S, at 363.

66. See, e.g., Carpenter v. Wabash Ry, Co., 309 U.S. 23 (1940), Carpenter, like The Schooner Peggy, is best understood as standing for decision-time law rather than decision-time result, The statute at issue explicitly provided for application to cases "now ... pending in any court of the United States." Id. at 27.

67. See, e.g., Vandenbark v, Owens-Illinois Glass Co, 311 U.S. 538 (1940).

68. Id.

69. Id at 543 . 
prospective results. If a state court ruled that its decision should be applied only prospectively, as Sunburst had held it might, Vandenbark would presumably require federal courts to follow this prescription.

Although the concept of prospectivity had been considered by the Supreme Court in 1932, it took substantially longer for the transaction-time model to win a place in its opinions. There were flickers of prospectivity in the $1950 \mathrm{~s},{ }^{70}$ but it was not until the late 1960s that these sparks found tinder. It was then that the Court found a need to engage in prospective overruling; it was then that the question of retroactivity truly emerged.

The Warren Court's revolutionary changes in criminal procedure produced an equally revolutionary change in retroactivity analysis. The Warren Court's first sustained discussion of retroactivity came in Linkletter $v$. Walker. $^{71}$ That case posed the question of retroactive application of Mapp v. Ohio, ${ }^{72}$ which had held the Fourth Amendment exclusionary rule applicable to the States. ${ }^{73}$ The rule announced in Mapp had been applied in that case, and to cases pending on direct review at the time of the Mapp decision. $^{74}$ The issue for the Linkletter Court was thus whether the Mapp rule could be invoked on habeas petitions by plaintiffs whose convictions had become final before the Mapp decision. ${ }^{75}$

The Court began with a historical discussion of the Blackstonian model and its erosion. It attributed to Austin a rival conception of law on which "judges do in fact do something more than discover law; they make it interstitially. ${ }^{.76}$ Locating the Austinian model in cases such as Gelpcke

70. See, e g, Griffin v. Illinois, 351 U.S. 12, 20 (1956) (Frankfurter, J., concurring); Mosser v. Darrow, 34 I U.S. 267, 275 (1951) (Black, J., dissenting).

71. 381 U.S. 618 (1965). In England v. Louisiana State Board of Medical Examiners, 375 U.S. 411 (1964). the Court had, without comment, refused to apply its holding to the parties before it Although Linkletter relied on England for the proposition that there was no Article III bartier to pure prospectivity, England offers only an inference from silence. The Linkletter Court's carefully phrased reference to England, "[N]o doubt was expressed of our power under Article III," Linkletter v. Walker, 381 U.S. $618,622 \mathrm{n} .3$ (1965), is tellingly precise nothing was expressed at all.

72. 367 U.S. 643 (1961)

73. See id at 657.

74. See, e g., Ker v. State of Califormia, 374 U.S. 23 (1964).

75. The question of how the Warren Court's new rules would apply to habeas petitioners had not gone unnoticed See, e.g., Paul M. Bator, Finality in Criminal Law and Federal Habeas Corpus for State Prisoners, 76 HARV, L. REV, 441, 527 n.220 (1963) (noting the "baffling problem" of habeas and retroactivity)

76. Linkletter, 381 US, at 623-24. Oddly, the Court concluded that on the Austinian model, earlier decisions that are overruled were wrongly decided. This conclusion follows directly from the Blackstonian model, and in fact the Austinian view allows one to avoid it by invoking the concept of changed law. Cf. Paul J. Mishkin, Foreword: The High Court, the Greal Writ, and the Due Process of Time and Law, 79 HARV L. REV. 56, 58 (1965) (stating that after beginning with Blacksione, "the opinion countered-somewhat unconventionally - with Austin"). The Court approached the idea that earlier decisions were correct when decided by characterizing them as "existing juridical fact[s] until overruied," which produces the same result. Linkletser, 381 U.S. at 624 
and Sunburst, it argued that earlier decisions were not erased by later overrulings. From this doctrine and other cases, including The Schooner Peggy and Vandenbark, it derived the propositions "(1) that a change in law will be given effect while a case is on direct review . . . and (2) that the effect of the subsequent ruling of invalidity on prior final judgments when collaterally attacked is subject to no set 'principle of absolute retroactive invalidity' but depends upon a consideration [of fairness and policy]." " "[]n appropriate cases," it concluded, "the Court may in the interest of justice make the rule prospective."

To decide whether the rule should be applied prospectively, the Court created a three-factor test of purpose, reliance, and effect. Because the purpose of the Mapp rule was not to exclude unconstitutionally obtained evidence but to deter unconstitutional searches, retroactive application of Mapp to habeas petitions would not further the purpose of the rule. This fact, coupled with the States' reliance on the earlier Wolf rule and the devastating (from the States' perspective) effect of application of Mapp to habeas petitions, led the Court to conclude that non-retroactivity was the sounder course.

The Linkletter analysis is deeply unsatisfying. First, it seriously misreads Gelpcke, Kuhn, and Vandenbark; consequently, it draws upon a historical tradition that does not exist. ${ }^{79}$ Second, it blithely assumes that Sunburst can be applied to federal courts despite the federal prohibition on advisory opinions. ${ }^{80}$ Most significantly, it draws a distinction between cases on direct review and those in which a judgment is collaterally attacked that is simply impossible to justify within its own theoretical model. ${ }^{81}$ Linkletter's petition (and Justice Black's dissent) made the obvious argument that the search in his case had occurred after the search in

77. Linkletter, 381 U.S, at 627

78. Id. at 628 .

79. Those cases are concerned with authority, not retroactivity-except to the extent that Vandenbark embodies the principle that courts must apply current law. Linkletler may also misread Sunburst. See Haddad, supra note 64, at 1063-64.

80. Sunburst dealt with prospectivity in state courts, which are often permitted to issue advisory opinions. Whether a prospective decision is advisory was thus not addressed.

81. In fact, the Court made no real attempt to justify it. The opinion discusses the general tendency against prospectivity, notes some cases that apparently suggest prospectivity is permissible. and mysteriously concludes that "under our cases" the two categories are to be treated differently. Linkletler, 381 U.S. at 627. Of course, no case mentioned in Linkietter had even discussed differentiating between direct collateral review-though to be fair, this is quite likely a consequence of the fact that the cases had not had to deal with much collateral review. The Linkletter Court, by contrast, found itself near the high-water mark of federal habeas corpus review of state judgments. See, e.g., Fay v. Noia, 372 U.S. 391 (1963), overruled by Wainwright v Sykes, 433 U.S, 72 (1977) But the problem remains: simply characterizing intermediate decisions as "existing juridical fact[s] until overruled" does not explain why the effects of their existence should depend on the procedural posture of a case, Linkletter, 381 U.S, at 624 
Mapp. ${ }^{82}$ The application of the Mapp rule to Mapp herself implied that, at the time of that search, the exclusionary rule applied to the States. Thus it would seem that it must necessarily have applied at the time of the later search in Linkletter. ${ }^{83}$ But even granting that the date of the Mapp decision is the relevant law-changing moment, the Court's approach is incoherent.

Its oddity has provoked substantial commentary, ${ }^{84}$ but it bears repeating. Consider two defendants implicated by evidence seized in a single invalid search. ${ }^{85}$ They are tried separately; both proceed to judgment at the same time. But while one judgment becomes final, the defendant in the other case avails himself of a lengthy appellate review, which is still ongoing when Mapp is decided. When the defendants seek relief on the basis of Mapp, the result will depend simply on whether or not the conviction has become final: the habeas petitioner will be told that there was no error in the conduct of his trial, and the defendant whose case comes on direct review will reap the benefit of Mapp. The evidence is inadmissible as to one but not as to the other, though it is fruit of the same search and may, indeed, be the same evidence.

The Linkletter result was almost inevitable. Allowing habeas petitioners to benefit from the Mapp rule would have produced an avalanche of habeas petitions and new trials. The burden on state criminal justice systems would have been intolerable; apart from the administrative cost of new trials, the states would have been forced to reassemble evidence and witnesses for cases whose original trials were now years in the past. ${ }^{86}$ But the rationale, or lack thereof, provoked fierce criticism. ${ }^{87}$ Clearly, retroactivity jurisprudence could not rest where Linkletter had placed it.

82. See Linkletter, 381 U.S. at $641-42$ (Black, J., dissenting).

83. The Court dealt with this contention by disagreeing: "The date of the seizure in Mapp has no legal significance. It was the judgment of this Court that changed the rule, and the date of that opinion is the crucial date. In the light of the cases of this Court, this is the better cutoff time." Id, at 639. The Court then cited The Schooner Peggy, putting an odd twist on a cryptic argument.

84. See, e.g. Francis X Beytagh, Ten Years of Non-Retroactivity A Critique and a Proposal, 61 VA. L REV 1557, 1565-66 (1975), Thomas S. Currier, Time and Change in Judge-Made Law: Prospective Overruling, 51 VA. L. REV. 201. 201-04 (1965); James B. Haddad, "Retroactivity Should be Reihought: "A Call for the End of the Linkletter Doctrine, $60 \mathrm{~J}$. CRM L. \& CRIMINOLOGY 417 (1969); Herman Schwartz, Retroactivity Reliability, and Due Process: A Reply to Professor Mishkin, 33 U. CHI. L. REV. 719, 764 (1966).

85. A more extensive "melodrama" based on this hypothetical is offered by Currier. See Currier, supra note 84, at 201-04.

86. See Mackey v, United States, 401 U.S. 667, 691 (1971) (Harlan, J., concurring),

87. See sources cited sipra note 84. Even Paul Mishkin, sympathetic to the Linkletter result. faulted the Court for its eryptic analysis and unnecessary abandonment of the Blackstonian declaratory model. Discussing the symbolic value of the declaratory theory, Mishkin commented, "If the view be in part a myth, it is a myth by which we live and which can be sacrificed only at substantial cost." Mishkin, supra note 76, at 62-63. 


\section{B. Modern Retroactivity Jurisprudence: The Question Confronted}

\section{Criminal Procedure}

Unable to distinguish between habeas petitions and direct review, yet unwilling to allow uniform retroactive application of new constitutional rules, the Court in Stovall v. Denno ${ }^{88}$ moved in the opposite direction. New rules had to be applied in the cases in which they were announced, lest constitutional adjudications "stand as mere dictum," cation to other cases, those on direct review and those presented on habeas petitions alike, would be judged by Linkletter's purpose-reliance-effect triad. ${ }^{90}$ Employing these factors, Stovall held that the new rule requiring the presence of counsel at exhibitions of accused parties to identifying witnesses would be applied only in the case in which it was announced. "Selective prospectivity" was born.

The Stovall regime of selective prospectivity achieved the goal of unifying the treatment of direct and collateral review, but it was a Pyrrhic victory. Selective prospectivity compounded the problems of the Linkletter approach. Linkletter's line between direct and collateral review had drawn a distinction without a difference, but selective prospectivity created differences without distinctions. The application of a rule to one defendant but not another, who might have participated in the same crime and been tried separately, was not merely unfair but openly incoherent when both cases came to the Court in the same procedural posture. If new law governed one case, for whatever reasons, it should govern the other, for precisely the same reasons. Legally correct results do not become incorrect by reason of iteration. ${ }^{91}$ The Stovall Court's justification for selective prospectivity, adherence to "sound policies of decision-making," is somewhat ironic in the face of Stovall's results. ${ }^{93}$ By refusing to apply in a

88. 388 U.S. 293 (1967).

89. Id. at 301 . On the transaction-time model, the concern is real, since the court is not declaring the rights of the parties before it but rather announcing how future cases will be decided.

90. See id. at 300. Under Stovall, results turned no longer on finality but rather on whether the conduct in question had occurred before or after the law-changing decision

91. If the fact of announcing a new rule is a relevant factor in the Court's decisionmaking process. this may not be true. For a suggestion that the Court's function of norm-promulgation should be primary, see Owen M. Fiss, The Supreme Court. 1978 Term-Foreword: The Forms of Justice, 93 HARV. L. REV. 1 (1979). Subsequent applications of new rules do not have the virtue of being vehicles for norm-promulgation. Individual Jitigants, however, certainly have a claim to see justice done on the merits of their individual cases, and it is true that this conception of justice requires consistency.

92. Stovall, 388 U.S. at 301.

93. One particularly unfortunate result of the new law/old law dichotomy was the consequent implication that the new rule was not the best reading of precedent but rather a legislative-style change effected by the will of the Court. See Williams v. United States, 401 U.S. 667.701 (1967) 
subsequent case the law it had announced governed the particular transaction at issue, Stovall achieved the all-but-impossible task of reproducing within the federal system the peculiar inconsistency that Swift v. Tyson had permitted between state and federal courts.

Although the Linkletter/Stovall regime survived well past the Warren Court, support was not unanimous even in its heyday. It was initially backed both by Justices who saw in non-retroactivity a means to implement desired reforms without inflicting unacceptable disruption on the criminal justice system and by those who disagreed with the reforms and accepted non-retroactivity as a way to limit their effect. The diverse bases for support reflected the underlying tensions in the doctrine. While selective prospectivity was hard to accept in theory, full retroactivity was impossible in practice. Yet distinguishing between cases on direct review and those presented by habeas petitions had proved impossible to do in a principled way within the transaction-time model. ${ }^{94}$

In a series of concurrences and dissents beginning in $1969,{ }^{95}$ Justice Harlan made a sustained attempt to craft a principled doctrine. He began with the premise that the Court's duty was to decide cases according to its best understanding of the law. ${ }^{96}$ It followed that selective prospectivity was unacceptable. "Simply fishing one case from the stream of appellate review, using it as a vehicle for pronouncing new constitutional standards, and then permitting a stream of similar cases subsequently to flow by unaffected by that new rule constitute an indefensible departure from this model of judicial review." ${ }^{97}$ New constitutional rules must therefore be applied to all cases on direct review. ${ }^{98}$

Habeas petitions presented different issues. Much as the Warren Court had in refusing to apply retroactively its expansions of the exclusionary rule, Justice Harlan looked to the purpose of the writ of habeas corpus as applied by the Warren Court. ${ }^{99}$ Finding it to serve a similar de-

(Harian, J, dissenting) ("[T]he retroactivity doctrine announced today bespeaks more considerations of policy than of legal principle"); Mishkin, supra note 76, at 65 ("Indeed, the conscious confrontation of the question of an effective date ... smacks of the legislative process."). The Warren Court's new rules thus took on a more starkly legislative cast. The Court's non-retroactive results suggested this legislative aspect, but it was not necessary to enshrine it in the theory.

94. See Stovall, 388 U.S at 300.

95. See Williams, 401 U.S. at 701; Elkanich v. United States, 401 U.S. 667 (1971) (Harlan, J., concurring); Mackey v, United States, 401 U.S. 667 (1971) (Harlan, J., concurring); Desist v United States, 394 U.S, 244, 256 (1969) (Harlan, J,, dissenting).

96. See Williams, 401 U.S. at 677-80; Desist, 394 U.S at 258-59.

97. Williams, $40 \mathrm{I}$ U.S. at 679.

98. See Desist, 39.4 U.S. at 258.

99. Justice Harlan addressed the Warren Court's conception of habeas corpus out of necessity, since his views that it "constitute[d] an indefensible departure both from the historical principles 
terrent function, "as a necessary additional incentive for trial and appellate courts throughout the land to conduct their proceedings in a manner consistent with established constitutional standards, ${ }^{\prime 100}$ he similarly concluded that application of decision-time law was not necessary to its purpose.

Justice Harlan thus concluded that with few exceptions, the law applied on habeas petitions should be the law in effect at the time of the initial trial. ${ }^{101}$ His view of the scope of the required exceptions changed slightly over time. Initially, he proposed that "'new" constitutional rules which significantly improve the pre-existing fact-finding procedures are to be retroactively applied on habeas," since one of the purposes of the habeas writ was to "assure that no man has been convicted under a procedure which creates an impermissibly large risk that the innocent will be convicted." 102 This exception was later abandoned in favor of a class defined by reference to the category of procedures "implicit in the concept of ordered liberty." 103 Justice Harlan's second exception was for rules "that place, as a matter of constitutional interpretation, certain kinds of primary, private individual conduct beyond the power of the criminal law-making authority to proscribe...."104

Reaching a different result in cases on direct review and those before the Court on petitions for habeas corpus was obviously attractive, as it would allow the Court to abandon the embarrassing doctrine of selective prospectivity without causing prison doors to swing too wide. Justice Harlan's distinction, however, had more to do with his different conception of habeas corpus than a new theory of retroactivity: "As regards cases coming here on collateral review, the problem of retroactivity is in truth none other than one of resettling the limits of the reach of the Great Writ, which under the recent decisions of this Court has been given almost boundless sweep." He recommended different treatment simply in order to respect the finality of prior adjudications. ${ }^{106}$ This reliance on finality did not provide a principled distinction easy to incorporate into the existing

\footnotetext{
which defined the scope of the 'Great Writ' and from the principles of federalism which have formed the bedrock of our constitutional development," had not prevailed. Id. at 262 .

100. Id at 262-63. The parallels between the treatment of habeas petitions and that of the exclusionary rule are striking. See Butler v. Mckeflar. 494 U.S. 407. 414 (1990): Penry v. Lynaugh. 492 U.S. 302, 351 (1989) (Scalia, J, concurring).

101. See Desist, 394 U.S at 263.

102. Id at 262 .

103. Palko v. Connecticut, 302 U.S. 319,325 (1937). Justice Harlan's example of this sort of procedure was the right to counsel established in Gideonv. Wainwright, 372 U.S. 335 (1963).

104. Williams v. United States, 401 U.S.667.692 (1971) (Harlan, J., dissenting).

105. Id at 701-02.

106. See id, at 690.
} 
jurisprudence of retroactivity. ${ }^{107}$

Though not perfect, Justice Harlan's approach was more attractive than the selective prospectivity of Stovall, and it exerted a gravitational pull. After Desist, the Court's attempt to differentiate habeas petitions from direct review followed a tortured path towards Justice Harlan's results. In Hankerson $v$. North Carolina, ${ }^{108}$ Justice White suggested in a footnote that the impact of retroactive application to habeas cases might be mitigated by the fact that defense lawyers were unlikely to make objections obviously futile under settled law: "The States, if they wish, may be able to insulate past convictions by enforcing the normal and valid rule that failure to object ... is a waiver of any claim of error." This idea received qualified endorsement in Engle v. Isaac, ${ }^{110}$ a case in which the Court rejected the argument that novelty excused a procedural default that would otherwise bar the raising of a claim on a habeas petition. ${ }^{\prime \prime \prime}$

The Hankerson-Engle approach offered a clever, if heartless, method of effectively denying retroactive relief to habeas petitioners. ${ }^{112}$ Its ultimate efficacy was never tested, however, because majority support emerged for the more direct approach advocated by Justice Harlan. In the 1987 case of Griffith v. Kentucky, ${ }^{113}$ the Court abandoned the LinkletterStovall analysis and accepted Justice Harlan's argument that "new rules" of criminal procedure must be applied retroactively to all cases pending on direct review. ${ }^{1 / 4}$ Two years later, in Teague $v$. Lane, ${ }^{115}$ the Court adopted Justice Harlan's approach to collateral attack as well: "Unless they fall

107. The most significant problem with a reliance on finality is that the finality interest is always present in a collateral attack. Finality, by itself, offers no reason to distinguish between challenges relying on old law and those urging the application of new law. See infra Part III.A.

108. 432 U.S. 233 (1977).

109. Id. at 244 n. 8 (citation omitted).

110. 456 U.S. 107 (1982).

111. See id at 130-31. The Engle Court reserved judgment on the question of whether novelty could ever establish cause for failure to object, reasoning that the grounds for the objection were available to petitioners at the time of trial.

112. The Hankerson-Engle approach was not without its critics. See Griffin v. Illinois, 35I U.S. 12,26 (1956) (Frankfurter, J, concurring) ("We should not indulge in the fiction that the law now announced has always been the law and, therefore, that those who did not avail themseives of it waived their rights.")

113479 U.S. 314 (1987). The progress towards Griffith was also a gradual one See Shea v Louisiana, 470 U.S. 51 (1985) (applying Johison to new Fifth Amendment rules): United States v. Johnson, 457 U.S. 537 (1982) (limiting non-retroactivity on direct review to new rules constituting "clear breaks" with precedent).

114. Although the Griffith Court quoted Justice Harlan's opinions with approval, it followed him at the level of result rather than that of theoretical model. See infra notes 252-57 and accompanying text.

115. 489 U.S. 288 (1989). 
within an exception to the general rule, new constitutional rules of criminal procedure will not be applicable to those cases which have become final before the new rules are announced." 16

For all its claimed fidelity, the Teague opinion departed from Justice Harlan's vision in two respects. First, it modified his suggested exceptions to the general rule. While adopting wholesale the principle that changes in law should be applied if they placed "primary private individual conduct beyond the power of the criminal law-making authority to proscribe," combined the two versions of the second exception he had proposed in Desist and Mackey. New rules would be applied only if they both required observance of procedures implicit in the concept of ordered liberty and contributed to the accuracy of the verdict. The Court suggested that the intersection of these categories would be extremely narrow. ${ }^{118}$

The second departure from the Harlan model was more significant. The Teague Court stated that recognition of the new rule urged by the petitioner would require its application to his case, lest "constitutional adjudications ... stand as mere dictum." 19 Yet the restrictions it had previously set forth would preclude application in other habeas cases. Since selective prospectivity "hardly comports with the ideal of "administration of justice with an even hand, ${ }^{\prime \prime} 120$ the Court concluded that the best practice was to "refuse to announce a new rule in a given case unless the rule would be applied retroactively to the defendant in the case and to all others similarly situated." 21

This reasoning was entirely consistent with Justice Harlan's position. Teague's difference lies in its conception of newness. ${ }^{122}$ Because Justice Harlan adhered to a model of adjudication on which "many, though not all, of this Court's constitutional decisions are grounded upon fundamental principles whose content does not change dramatically from year to year, but whose meanings are altered slowly and subtly as generation succeeds generation," ${ }^{\prime \prime 23}$ he saw a relatively small class of cases as announcing rules sufficiently new to bar application on habeas petitions. The current Court,

116. Id at 310 .

117. Id. at 311 (citation omitted).

118. Indeed, since Teague, no such rule has been discovered. See RICHARD H. FALLON, JR. EI AL., HART AND WECHSLER'S THE FEDERAL COURTS AND THE FEDERAL SYSTEM 1409 (4th ed. 1996)

119. Teague, 489 U.S. at 315 (quoting Stovali v. Denno, 388 U S. 293, 301 (1967)).

120. Id. (quoting Desist v. United States, 394 U.S. 244, 255 (1969) (Douglas, J.. dissenting)).

121. Id. at 316 .

122. See id at 301 (stating that "a case announces a new rule if the result was iot dictated by precedent").

123. Id. at 263 
by contrast, has embraced a very broad conception of new law. ${ }^{124}$ The current retroactivity jurisprudence in criminal law has thus moved towards bright-line rules - retroactivity on direct but not collateral review - and away from the underdetermined Linkletter balancing. Its distinction between direct and collateral review, and its consistent focus on transactiontime law, however, brand it as Linkletter's intellectual descendant and, more significantly, as a product of the transaction-time model. ${ }^{125}$

\section{Statutes of Limitations}

The retroactivity jurisprudence developed in the criminal context did not carry over to civil actions of its own force. In Chevron Oil Co, v. Huson, ${ }^{126}$ however, the Court adopted an approach very similar to the Linkletter analysis. Chevron arose from a personal injury suit under the Outer Continental Shelf Lands Act. ${ }^{127}$ When the case was filed, circuit precedent held that admiralty law, including the equitable doctrine of laches, applied to such claims. While pretrial discovery was underway in the district court, however, the Supreme Court decided Rodrigue v. Aetna Casualty and Surety Co., ${ }^{128}$ holding that state statutes of limitations were to be absorbed and applied as federal law under the Outer Continental Shelf Lands Act. ${ }^{129}$ Under the Lousiana one-year statute of limitations for personal injury suits, Huson's suit was time-barred two years before it was filed, and the district court accordingly granted summary judgment against him. ${ }^{130}$

The Supreme Court disagreed. Citing its criminal law precedents as well as a number of civil non-retroactivity cases, it set forth a three-factor test related to the Linkletter analysis. The first element was a threshold determination that the decision to be applied non-retroactively "estab-

124. See, e.g., Butler v. McKellar, 494 U.S. 407 (1990), see generally Fallon \& Meltzer, supra note 42 , at 1748 (stating that "[t]he conception of legal newness implicit in Teague and its progeny is difficult to reconcile with the conception of the judicial role embraced by Justice Harlan"). The current Court's broad conception of new law may be understood in part as an attempt to limit the reach of habeas petitions. It is also, 1 believe, a consequence in part of the dominance of the transaction-time model. Because this model suggests that judicial lawmaking is akin to legislative lawmaking, it makes even incremental changes in law appear discretionary innovations rather than logical extensions of precedent. While this conception may have the desired result of reducing the scope of habeas, it undermines the legitimacy of judicial review.

125. The markers of the transaction-time model are Griffith's insistence on applying new law retroactively - in order to change the law that governed at the time of the transaction - and Teague's admission that finaity is the best justification that can be offered for differential treatment of direct and collateral review. See infra notes $242-45$ and accompanying text

126. 404 U.S. 97 (1971).

127. 43 U.S.C. $\$ \$ 1331-1356$.

128. 395 U.S. 352 (1970).

129. See id at 355 (referring to 43 U.S.C. $\$ \$ 1331-1356$ ).

130. See Chevron, 404 U.S at 99. 
lish[ed] a new principle of law, either by overruling clear past precedent .. . or by deciding an issue of first impression whose resolution was not clearly foreshadowed." "131 The second factor absorbed the Linkletter criteria, condensing them into an analysis of the purpose of the new rule. The third was a balancing of equities. ${ }^{132}$

Based on this analysis, the Court concluded that the Rodrigue rule should not be applied retroactively. The Rodrigue decision had overruled clear circuit precedent; the purpose of the rule was to aid injured employees like Huson; and holding Huson to have "slept on his rights" when he could not have known that state law applied would be inequitable. ${ }^{133}$

The three-factor Chevron test sprang from the same principles animating the Linkletter analysis. The similarity between criminal and civil contexts was not surprising; Linkletter had drawn upon civil precedents and stated that historically "no distinction was drawn between civil and criminal litigation. ..."134 Notwithstanding Linkletter's observation, this uniformity did not persist. In 1987, the Court decided Griffith v. Kentucky, and automatic retroactivity became the rule for criminal cases on direct review, while Chevron was relegated to the civil arena. ${ }^{135}$

As late as 1987, Chevron was employed to prevent retroactive application of a decision altering the statute of limitations, in Saint Francis College v. Al-Khazraji. ${ }^{136}$ By 1991, the tide of retroactivity, however, was rising. In Lampf, Pleva, Lipkind, Prupis \& Petigrow v. Gilbertson ${ }^{137}$ the Court retroactively applied its adoption of a federal statute of limitations for suits under Rule $10 \mathrm{~b}-5^{138}$ of the Securities Exchange Act ${ }^{139}$ with no mention of either Chevron or non-retroactivity. Justices Stevens and Souter, dissenting, criticized the majority for "undertak[ing] a lawmaking task that should properly be performed by Congress" 140 and noted the diffi-

\footnotetext{
131. Id. at 106 (citations omitted)

132. See id at 106-07.

133. See id at 108 (citation omitted)

134. Linkletter v. Walker, 381 U.S. 618,627 (1965).

135. See Griffith $\times$. Kentueky, 479 U.S. 314, 322 n 8 (1987).

136. 481 U.S. 604 (1987). The Saint Francis plaintiff had filed his suit in 1980, and Third Cireuit cases starting in 1977 had held that a six-year statute of limitations (rather than the two-year limitations period the Third Circuit announced in 1985) governed his claim. Interestingly, one month later the Court decided the appeal of the law-changing circuit court decision. The original complaint in that case, Goodman y. Lukens Steel Co., 482 U.S. 656 (1987), had been filed in 1973. Reasoning that the law in 1973 was unsettled and the plaintiff could not have relied on circuit precedent establishing the six-year limitations period, the Court held that the new rule specifying the two-year statute of limitations should apply. This created a sort of hopscotch retroactivity: The new rule was applied to the 1973 action. but the old one was applied to the 1980 action.
}

137. 501 U.S. $350(1991)$

138. 17 C.F.R $\$ 240.10 b-5(1998)$

139. 15U.S.C. \& 78j(b) (1994).

140. Lampf. 501 U.S. at 366 (Stevens. J., dissenting) 
cult questions of retroactivity created by judicial decisions based on policy determinations. ${ }^{141}$ Justices $\mathrm{O}^{\prime}$ Connor and Kennedy, invoking Chevron and Saint Francis, criticized the majority's silent disposition of the retroactivity question for both its disposition and its silence. ${ }^{142}$

One plausible explanation for those features of the majority opinion, as mentioned in Part I, is the positive source of the law being applied. Lampf involved an interpretation of Section 10b-5, an unchanging statute; $;^{i 43}$ one might plausibly think that since the statute had not changed, the law had not either, and the Court's decision therefore raised no retroactivity issues at all. This understanding of statutory interpretation would avoid the pitfalls of the transaction-time model, by avoiding the question of retroactivity entirely. But while positive source does affect the plausibility of characterizing overruling decisions as "changing the law," the Court has never distinguished between statutory and constitutional adjudication, ${ }^{144}$ and its statute of limitation retroactivity decisions do work within the transaction-time model.

Lampf is thus probably better understood as simply evidence of the growing influence of Griffith. There is, after all, no obvious reason to

141. See id, at 367-68

142. Like Saint Francis and Goodman, Lampf and its consequences have a story worth telling. Six months after Lampf, Congress added Section 27A to the Securities Exchange Act. Section 27A(a) overruled Lampf for cases pending when it was handed down; with respect to cases still in court. this was clearly constitutionally acceptable. Section $27 \mathrm{~A}(\mathrm{~b})$ went further, attempting to reinstate those of the cases that had been dismissed as time-barred as a result of the Lampf decision. This latter section spawned a cottage industry of commentary and bad puns. See. e.g., Patrick T. Murphy. Note, Section 27A of the SEA: An Unplugged Lampf Sheds No Constitutional Light, 78 MINN, L. REV. 197, 211-12 (1993); Craig W. Palm. The Constitutionality of Section 27A of the Securities Exchange Act; Is Congress Rubbing l.ampf the Wrong Way?, 37 VILL. L. REV. 1213, 1213 (1992); Anthony Michael Sabino, A Statutory Beacon or a Relighted Lampt? The Constitutional Crisis of the New Limitary Period for Federal Securities Law Actions, 28 TULSA L.J. 23, 61-64 (1992). In Plaut v. Spendthrift Farm. Inc. 514 U.S. 211, 240 (1995), the Court struck down Section 27A(b) as an unconstitutional infringement on the separation of powers, fulfilling in part Justice Kennedy's prediction. See Lampf. 50 I U.S at 379 (Kennedy. J., dissenting) (stating that even congressional action would "not avail defrauded investors caught by the Court's new and unforgiving rule"). The result of the Lampf-27APlaut three-step was thus that litigants who, though time-barred under Lampf, had managed to hang on until the passage of 27A had the sword tifted. But even that was not the end. Section 27A said nothing about untiled cases, and in a final twist, investors defrauded before Lampf but who had not filed suit at the time Lampf was decided had their claims subjected to the new. shorter limitations period.

143. See Lamp/, 501 U.S. at 352 .

144. Nor does positive source work very well as a policy justification the reliance interests of parties who put their trust in judicial opinions cannot be meaningfully distinguished based on whether those opinions interpret statutes or the Constitution. This sort of metaphysical answer to a practical problem is characteristic of some retroactivity scholarship, see infra notes $171-81$ and accompanying text, but its arid tormalism is quite unappealing. As Part 111 argues infra, there is a better way. 
distinguish between civil and criminal suits, ${ }^{145}$ and the tension between Chevron and Griffith was bound at some point to erupt into openly acknowledged conflict. Lampf clearly suggested that Chevron was in difficulty, and the tide of retroactivity overtopped the barrier between criminal and civil cases in the succession of tax refund suits decided between 1989 and 1993.

\section{Tax Refunds}

It is a well-settled principle of law that a state must provide retrospective relief from an unlawful tax if it does not provide the taxpayers with a meaningful opportunity for prepayment challenge. ${ }^{\text {lat }}$ This relief need not take the form of a refund; if, for example, a tax violates the Equal Protection Clause, the state may remedy the violation by imposing additional taxes retrospectively to equalize the discriminatory treatment. ${ }^{147}$

Cases in which a tax is clearly unconstitutional when enacted thus present no real issue of retroactivity: Purely prospective relief for coerced payments is inadequate as a matter of due process. ${ }^{148}$ The difficult question from the retroactivity perspective is what result obtains when a tax was not clearly unconstitutional when enacted but became so as a result of subsequent Supreme Court decisions.

American Trucking Ass' $n s$ v. Smith ${ }^{149}$ confronted, but did not resolve, this question. The Smith plaintiffs challenged an Arkansas trucking tax as a violation of the dormant Commerce Clause. ${ }^{150}$ While the case was pending, the Court decided American Trucking Ass'ns v. Scheiner, ${ }^{151}$ which held unconstitutional a similar Pennsylvania tax. ${ }^{152}$ In Smith, Justice

145. But see American Trucking Ass'ns v. Smith, 496 U.S. 167, 197-99 (1990) (setting forth justifications for disparate treatment of criminal and civil cases). Justice O'Connor's attempt to reconstrue the history of retroactivity doctrine is valiant but ultimately unpersuasive. Linklefter clearly did not see the differences she posits; it does not draw the distinction and in fact denies it. See Linkletter v Walker, 381 U.S. 618, 627 (1965). More seriously, Justice O'Connor's proposed distinction encounters serious difficulties when the same law is implicated in both civil and criminal contexts. Fallon and Meltzer offer the following example: if a state brings both civil and criminal nonpayment actions against a delinquent taxpayer, and the tax is held unconstitutional by a decision rendered while the cases are on appeal, different results in the criminal and civil spheres will imply that the tax was both constitutional and unconstitutional at the time of the nonpayment. See Fallon \& Meltzer, supra note 42, at 1767-68. This makes law rather too much like quantum physics; a tax statute is no Schroedinger's cat.

146. See, e.g, McKesson Corp. v. Division of Alcoholic Beverages \& Tobacco, 496 U.S. 18, 22 (1990): Ward v. Love County, 253 U.S. 17, 24 (1920)

147. See Reynoldsville Casket Co v. Hyde, 514 U.S. 749, 755 (1995).

148. See Harper v. Virginia Dep't of Taxation, 509 U.S. 86, 101 (1993)

149. 496 U S 167 (1990)

150. See id.

151. 483 Uj,S. 266 (1987)

152. See id at 269. 
O'Connor, writing for a plurality of four, ${ }^{153}$ employed the Chevron threefactor analysis and concluded that Scheiner should not be applied to taxes for highway use prior to the date of that decision. ${ }^{154}$

Like the Stovall regime, the Smith approach drew support from very different camps. While the plurality favored selective prospectivity and sought to contain Griffith within the criminal sphere, Justice Scalia, who provided the fifth vote for the non-retroactive result in Smith, did so because he believed that the holding of unconstitutionality was incorrect. ${ }^{153}$ This position bears an obvious similarity to Justice Harlan's early pragmatic tendency to accede in selective prospectivity out of a desire to limit the effect of reforms he found unwise. Scalia's theoretical justification, however, was a neo-Blackstonianism that most closely resembles the position of the Gelpcke Court. Conceding the authority of the Scheiner opinion as a matter of stare decisis, he denied its correctness and refused to be bound on pre-Scheiner questions. ${ }^{155}$ The principle underlying this position, the same as that driving the opinion in Gelpcke, is that while an incorrect decision may compel a judge to acquiesce in a subsequent case, it does not change the true (prior) law. ${ }^{157}$ For Justice Scalia, the result in Smith turned on authority, not retroactivity; the question was to what extent he was bound to adhere to a decision with which he disagreed. ${ }^{158}$

On the question of retroactivity, Justice Scalia, like the four dissenters, ${ }^{159}$ emphatically denied the propriety of - prospective decisionmaking. Thus while Justice O'Connor mustered five votes in favor of a selectively prospective result, the theoretical alignment was a five to four split against prospectivity entirely. Where the plurality sought to cabin

153. The plurality was composed of Justices O'Connor, White, and Kennedy and Chief Justice Rehnquist.

154. See Smith, 496 U.S, at 178-83. The Court's treatment of retroactivity as a federal question was inconsistent with Scheiner, which had remanded to the Pennsylvania Supreme Coun for a consideration of retroactivity. See Scheiner, 483 U.S. at 297-98. The Pennsylvania court held that Scheiner should be applied purely prospectively, and the taxpayers received only a pro-rated refund for the year in which Scheiner was decided. See American Trucking Ass'ns v. MoNulty. 596 A, 20 784. $790(\mathrm{~Pa}$ 1991).

155. See Smith 496 U.S. at 202-04 (Scalia, J, concurring)

156. See id. at 204-05 (Scalia, J., concurring).

157. Arguably, if Scheiner had claimed to apply its new rule retroactively, it would have constituted an authoritative statement of transaction-time law, binding Justice Scalia to a similat result in Simith. The Scheiner Court, however, remanded for a consideration of retroactivity, and the Penrisylvania court held in favor of prospectivity. See supra note 154

158. See Smith, 496 U.S. at 204-05 (Scalia. J., concurring).

159. Compare Amcrican Trucking Ass'ns v. Smith, 496 U.S. 167, 201 (Scalia, J, concurring) ("[P]rospective decisionmaking is incompatible with the judicial role ...."), with id at 21.4 (Sievens. 1. dissenting) ("[A]dherence to legal principle requires that we determine the rights of litigants in accordance with our best current understanding of the law.") 
Griffith, the dissent urged its expansion. ${ }^{160}$ Given the clear support of Justice Scalia, there was no doubt that a majority of the Court was willing to bring Griffith into the civil arena.

When the Court decided its next tax refund retroactivity case in 1991. Justice Souter had replaced Justice Brennan. Any hopes this shift might have kindled in foes of Griffith were swiftly dashed. James B. Beam Distilling Co. v. Georgia ${ }^{\text {tor }}$ produced five opinions, none of which commanded more than three votes. Majority trends were evident, however. Six Justices rejected selective prospectivity, and three of those condemned any sort of prospectivity at all. ${ }^{162}$ Two years later, Harper v. Virginia Department of Taxation ${ }^{163}$ found five Justices explicitly extending Griffith's mandate of equal treatment for similarly situated parties to civil cases, and selective prospectivity was finally interred. ${ }^{164}$

\section{Summary}

Given the complexity of the retroactivity jurisprudence, it is worth pausing at this point to recapitulate at a slighter higher level of generality. I have divided the analysis by subject matter in order to display the progress of the Court's reasoning in similar cases; the result of unifying the picture may resemble the blind men's experience of the elephant. The disparate narrative threads combine to form a somewhat tangled tapestry, and the following summary may lack aesthetic unity. Life does not always imitate art.

The basic outlines, however, should be relatively clear. Nonretroactivity emerged in the criminal context with Linkletter $v$. Walker

160. See id at 214 (Stevens, J., dissenting).

161. 501 U.S 529 (1991). Beam featured a fact pattern similar to Smith. A 1984 decision, Bacchus Imporls, Ltd v. Dias, 468 U.S. 263, 276 (1984), had struck down a Hawaii tax as violating the Commerce Clause. The Beam plaintiff sought refunds for monies collected under a very similar Georgia tax. That the tax was unconstitutional was clear: Georgia had repealed it in 1985. See Beam, 501 U.S. at 532. The question was whether relief was available for pre-1984 taxes, i.e., whether Bacchtis was retroactively effective. See id.

162. Justices Blackmun, Marshalt, and Scalia railed against prospectivity. See Beam, 501 U.S. at 547 (Blackmun, J., concurring), id at 548 (Scalia, J., concurring) Justice Souter, delivering the opinion of the Court despite being joined only by Justice Stevens, rejected selective prospectivity, and stated that "Griffith cannot be confined to the criminal law." Id at 540. Justice White also concurred, rejecting selective prospectivity but adding that he believed Griffith had been wrongly decided. See id. at 545 (White, J concurring).

163. 509 U.S. 86 (I993).

164. See id. at 90 . The continuing vitality of pure prospectivity is highly questionabic. Justice White, writing separately in Beam, criticized Justice Souter's opinion for reserving the question and thereby suggesting doubts. See Beam, 501 U,S, at 546. Pure prospectivity does retain the support of at least three current Justices (O'Connor, Kennedy, and Rehnquist). For reasons relating to the limitations of their theoretical approach, however, it seems unlikely that pure prospectivity will resurface. See infra note 277 and accompanying text. 
(1965). Stovall v. Denno (1967) provided for unified treatment of cases on direct review and those presented by habeas petitions and permitted selective prospectivity. Chevron Oil v. Huson (1971) extended prospectivity into the civil arena. Criminal law, meanwhile, was becoming increasingly inhospitable to selective prospectivity, and Griffith v. Kentucky (1987) rejected it. Teague v. Lane (1989), following Justice Harlan, announced restrictive standards for the availability of retroactive relief to habeas petitioners.

Griffith proved impossible to contain within the criminal sphere, and in Harper v. Virginia Department of Taxation (1993), the Court embraced Griffith's mandate of equal treatment in civil cases as well: If a new rule is applied in the decision that announces it, it must be applied in subsequent cases on direct review. In consequence, retroactive results have reassumed the primacy they enjoyed before the Warren Court's innovations. (The most recent retroactivity decision, Reynoldsville Casket Co. v. Hyde, breaks new ground only in its treatment of the remedies; it is discussed in detail infra Part III.)

The end of all the Court's explorings has been to arrive, more or less, where it started: "New" legal rules are applied to cases on direct review but not to those presented collaterally. ${ }^{165}$ But while the current Court reaches much the same results as it would have before it embarked on its non-retroactivity odyssey, there is a significant theoretical difference. The concept of retroactivity has emerged, and the question of retroactivity stands now as one of the knotty problems of our jurisprudence. It is not the Everest of legal theory, the central concern that the countermajoritarian difficulty was for Bickel's generation of scholars, but it is a difficult subject that has attracted the attention of a number of talented and ambitious legal thinkers. The next section considers the efforts of the academy to answer the question of retroactivity.

165. Because the availability of collateral review used to be much narrower, the pre-Linkletter treatment of collateral review is rarely displayed. Chicot County Drainage Dist. v. Baxter State Bank, 308 U.S. 371 (1940), is the most illuminating pre-Warren Supreme Court decision featuring a collateral attack arguing for the application of new law, and it rejects the argument because of the collateral nature of the challenge. See id. at 376-77. Interestingly, courts and commentators seem to think that the historical approach would have been to decide collateral attacks based on new law - this fear was, after all, what necessitated Linkletter's "strong reading" of its precedents. Sie, e.g, Linkletter v. Waiker, 381 U.S. 618, 628-29 n.13 (1965) (listing Warren Court cases applying new law to collateral attacks): Daniel J. Meador, Habeas Corpus and the "Retroactivity" Illusion, $50 \mathrm{VA}, \mathrm{L}$. REV - 1115, 11 16-20 (1964) (arguing for application of new law to habeas petitions). Thus, the irony of the Warren Court's retroactivity jurisprudence is that, as Part 111 demonstrates, not only was the cure worse than the disease, but there was no disease at all. Linkletter created the very probiem it tried unsuccessfully to solve. 


\section{Modern Retroactivity Scholarship: The Question Answered?}

Academics show rare consensus in their estimation of the Court's performance: it is unsatisfactory. James Haddad laments that "doctrinal confusion and inconsistency are the hallmark of nonretroactivity jurisprudence." 166 Jill E. Fisch comments that "the Supreme Court's recognition of the intellectual poverty of its retroactivity analysis has led to efforts to formulate a more rational analytical structure, albeit with limited success." ${ }^{\prime 167}$

The general dissatisfaction with the Court's retroactivity jurisprudence has not produced a corresponding consensus on the appropriate alternative. One scholar seems to think there is no problem; ${ }^{168}$ others believe that the question of retroactivity is best understood as a question of remedies; $;^{169}$ still another suggests that retroactivity analysis should be guided by a model of equilibrium drawn from physics. ${ }^{170}$. The following sections take up these attempts to answer the question.

\section{Metaphysical Answers to Practical Questions}

\section{a. Ronald Dworkin's Neo-Blackstonian Approach}

Ronald Dworkin's critique of positivism provides a clear statement of the principles underlying the transaction-time model: retroactive application of the law is unjust, and consequently the morally relevant rights and duties are the ones existing (i.e., legally recognized) at the time of the transaction. ${ }^{171}$ He faults positivism precisely because it suggests that judicial decisions retroactively impose new duties, and his theory of adjudication is designed to do away with this unfairness. ${ }^{172}$ Dworkin's positive theory maintains that legal decisions enforce pre-existing rights, and that right answers exist in almost all cases. ${ }^{173}$ As a result, Dworkin sees judicial decisions as best readings of settled law conjoined with principles of justice and endorses decision-time results as the correct statement of trans-

166. Haddad, supra note 64, at 1062 (citing Beytagh, supra note 84, at 1558-96; John Bernard Corr, Retroactivity: A Study in Supreme Court Doctrine "As Applied," 61 N.C. L. REV. 745, 748-63 (1983)).

167. Fisch, supra note $I$, at 1058 .

168. See infra Part II.C,I

169. See Fallon \& Meltzer, supra note 42 , at 1733.

170. See Fisch, supra note 1. at 1056.

171. See DWORKIN, supra note 23, at 81-85.

172. See id at $81-85,335 ; \mathrm{R}$. Lea Brilmayer, The Institutional and Empirical Basis of the Rights Thesis, 11 GA. L. REV 1173, $1175-76$ (1977); Kenneth J. Kress, Legal Reasoning and Coherence Theories: Dworkin's Righis Thesis, Retroactivity, and the Linear Order of Decisions, 72 CAL. L. REV. $369,373-74$ (1984)

173. See DWORKIN, supra note 23, at $87,279-80$; see also RONALD DWORKIN. A MATTER OF PRINCIPLE 119-45 (1985): Kress, supra note 172. at 374. 
action-time rights.

This unification of decision- and transaction-time law seems to do away with the problem of retroactivity, just as the Blackstonian model did. If a judicial decision is simply the best reading of the law, then it produces not only the just but the legally correct answer, and there is no issue of retroactively imposing new duties on parties before the court.

A first criticism of Dworkin's account is that metaphysical solutions do not resolve practical problems. The key issue of retroactivity is one of unfairness, not injustice. That is, the problem in applying decision-time law is not so much that the morally relevant rights and duties are transaction-time, but that it is unfair to parties to judge them by law about which they had no way of knowing. Dworkin's argument that an overruling decision is simply the best reading of pre-existing law may solve the metaphysical problem, but it is cold comfort for parties who relied on clear precedent. ${ }^{174}$

A second criticism is that just rules and just results may not always coincide; the reasons that make a new legal rule right may not make that rule's result right in the case before the court. The Warren Court's analysis of the purpose of the exclusionary rule, and its conclusion that retroactive application would not further the principles of justice animating the rule's expansion, provide an example of such a case. For another instance of rule/result mismatch, consider a situation in which lower courts have regularly borrowed state statutes of limitation to govern an implied federal right of action. When the question is argued before the Supreme Court, the Court decides that a uniform federal statute of limitations will better serve justice by promoting uniformity and predictability. ${ }^{175}$ This reasoning is quite convincing; what is harder to see is how uniformity and predictability are served by applying the new federal statute of limitations to cases pending on direct review. Thus the answer that seems right as a matter of theory may still work obvious injustice to the parties before the court.

Both the preceding criticisms are external. They accept Dworkin's claims about how his model works and then take issue with the results. Both criticisms, further, are contestable. It is possible to argue that vindicating pre-existing rights and duties is morally paramount regardless of whether parties can know what those duties are, and it is possible to argue that a Dworkinian judge will never reach a rule that, if applied, fails to

174. See Stephen R. Munzer, Right Answers, Preexishng Rights, and Fairness, II GA L. REV 1055. 1061-62 (1977). But see DWORKiN, supra note 23, at $335-36$ (rebutting Munzet, noting that faimess enters into decisional calculus).

175. See Lampf, Pleva, Lipkind, Prupis \& Petigrow v Gilbertson, 501 U.S. 350. 361-62 (1991). 
produce justice in the case before him.

There exists a third criticism, however, which is internal to Dworkin's theory and more obviously devastating in its effect. It has been developed at length by Kenneth Kress, ${ }^{176}$ and I recapitulate the argument only briefly. What Kress's argument shows is that even within Dworkin's theory, judicial decisionmaking can produce results that differ between transaction and decision time. Dworkin's analysis fails to take into account the extent to which intervening decisions, by changing the settled law, can alter the calculus that judges perform.

The point is as follows. Dworkin advocates a sort of coherentist analysis, asking which result shows the body of preexisting law in its best light. ${ }^{177}$ That analysis reveals the rights the parties held at the time of their actions, and it is those rights the court must vindicate. This would be well and good if litigation were instantaneous. But it is not; between a transaction and its judicial resolution, many other judicial decisions may intervene. These change the preexisting law, but they cannot be ignored - they are, after all, right answers. Since the body of preexisting law changes with intervening decisions, it seems clear that an intervening decisioneven one not directly on point ${ }^{178}$ - can change the result in a pending case. $^{179}$ In short, "legal rights depend upon the temporal order in which cases are decided." 180 Thus decision-time and transaction-time law are not necessarily the same on Dworkin's model: Depending on which cases are decided between the transaction and its legal resolution, the "correct" result may vary. And thus the Dworkinian approach does not provide even a metaphysical solution. ${ }^{181}$

\section{b. The Answer from Positive Source}

What I have said about the influence of positive source on our intuitive understandings of retroactivity might suggest that a happy resolution

176. See Kress, supra note 172, at 369 .

177. See RONALD DWÓRKIN, LAW'S EMPIRE $225-75$ (1986).

178. Dworkin has lesser problems with intervening decisions that are directly on point, since their results, as best readings, are presumably also correct for later cases.

179. This must be the case unless all possible legal decisions can be derived from the body of settled law existing at any particular time. Dworkin does not urge this hyperformalist proposition, and with good reason; since reliance interests count in his calculus of justice, the existence of a legal rule as part of the settled law will have effects quite different from those of its existence in some metaphysical heaven of "right answers."

180. Kress, supra note 172 , at 372 .

181. The works of Dworkin that I cite are not centraily concerned with retroactivity, and it may seem a bit unfair to take him to task for problems with his answer to a question he does not ask. But the problems are not tangential: they unravel his account of adjudicative legitimacy. Furthernore, insofar as it is the retroactive element of positivist adjudication with which Dworkin finds fault. retroactivity is a prime concern of his jurisprudential theory. 
would be to determine retroactive effect by reference to the positive source of the changed law. Thus new statutory interpretations would be given retroactive effect in all cases, and new common law rules in none. Constitutional decisions, of course, would be harder, but perhaps they could be identified as either best readings of existing precedent or discretionary changes of the law, and given retroactive effect in the former but not the latter case. This is, I think, the soundest metaphysical approach; that it does not appear to have been suggested by any scholar is perhaps a testament to the academy's sound pragmatic instincts. ${ }^{182}$

A moment's reflection should show that this is no solution at all. First, the statutory/common law distinction bears no relation to any of the factors that are appropriately weighed in a retroactivity balancing test such as Linkletter's purpose-reliance-effect triad. (This is not to say that such balancing tests are a good solution, only that distinctions unrelated to the standard concerns of fairness and efficiency ${ }^{183}$ are worse.) Second, the solution with respect to constitutional law is unworkable. The distinction between "best readings" and discretionary "judicial legislation" turns in part on questions of legal philosophy such as whether principles are part of the law; as a result, disagreement will present itself at a level of philosophical generality not conducive to the creation of stable, consistent doctrine ${ }^{184}$ This clash of jurisprudential philosophies is precisely the evil to be avoided. If some judicial decisions appear unpleasantly legislative, that is a problem of judicial philosophy, not of retroactivity ${ }^{185}$ and the question of what law to apply cannot be resolved at the philosophical level.

\section{Remedial Analysis: Fallon and Meltzer}

Professors Fallon and Meltzer have recently suggested that retroactivity issues are best analyzed within the law of remedies. ${ }^{186}$ The conclusion of this Article will be that remedial analysis is the only acceptable route to prospective results, and in this respect Fallon and Meltzer are clearly correct. Moreover, their general impulse-to dispense with high theory in favor of practical analysis-is refreshing and welcome. Yet the move to

182. Indeed, Fallon and Meltzer specifically (and correctly) characterize the jurisprudential debate over whether new law is made or found as a waste of time. See Fallon \& Meltzer. supra note 42 , at 1764

183. Fisch identities these as the leading prudential factors, see Fisch, supra note 1, at 1084-91, which seems correct, although she also seems to conflate utilitarianism with fairness. See id at 108586.

184. See Fallon \& Meltzer, supra note 42, at 1762.

185. See Shea R. Louisiana, 470 U.S. 51, 62 (1985) (White, J, dissenting) ("[C]oncerns about the supposed usurpation of legislative authority by this Court generally go more to the substance of the Court is decisions than to whether or not they are retroactive.")

186. See Fallon \& Melizer. supra note 42, at 1743. 
pragmatism occurs a bit too early. Fallon and Meltzer do not investigate the theoretical commitments of the Court's model, but an understanding of these commitments is essential to understanding the ways in which the model has warped the doctrine. An analysis that proceeds solely on the basis of predictability sets difficult line-drawing tasks; litigation occurs precisely because legal results are unpredictable, and when unpredictability rises to a sufficient level to warrant remedial adjustment is a question with no obvious solution. More seriously, by turning to a remedial analysis that is not based on any theoretical account of retroactivity, Fallon and Meltzer succumb to some of the perennial lures of retroactivity analysis and end up repeating some of the Court's gravest missteps.

For instance, Fallon and Meltzer endorse Stovall's selective prospectivity on direct review. ${ }^{187}$ Formalism may be a vice, but incoherence is no virtue, and incoherence is what selective prospectivity brings. The idea that getting to the Court first is a legally significant distinction - even in a remedial calculus - between otherwise identical cases is terribly hard to justify. Similarly, distinguishing between direct and collateral review requires more than an appeal to the value of finality and the danger of disruption. These concerns are always presented by collateral attacks and ordinarily do not overcome a constitutional violation in the conduct of a trial. Absent some relevant theoretical difference between new law and old law-which the transaction-time model obliterates and remedial analysis does not replace-finality does not distinguish between habeas petitions relying on new law and ones urging violations of old law. Nor does it satisfactorily distinguish between habeas petitions and cases on direct review, since the states' interests in avoiding disruption and the defendants' interests in application of the new rule are quite similar in both types of cases ${ }^{188}$

Finally, by viewing appellate review through the lens of remedies, Fallon and Meltzer neglect the significant fact that courts do not merely award or withhold remedies; they decide cases and articulate the law. True, what an appellant seeks is a reversal, and the reversal may be characterized as a remedy for a past violation - though once we leave the area of constitutional criminal procedure, this description becomes significantly less attractive - but the appellant will also get a statement of what the law

187. See id at 1807 .

188. See Griffith v. Kentucky, 479 U.S. 314, 332 n.1 (1986) (White, J., dissenting) (arguing that finality fails to distinguish between cases on direct and collateral review). White's argument that the burdens on the states are identical is overstated: although some habeas petitions will feature trials occurring later than some cases on direct review, habeas petitions as a class are likely to feature older trials, for which witnesses and evidence are more difficult to reassemble. That finality is not the distinguishing feature, however, seems quite true. 
is, and ascertaining what the law is requires more than a remedial analysis.

Remedial considerations have a large, and perhaps a dominant, role to play in a sound retroactivity doctrine. Remedial analysis, however, must be grounded in a determination of what law applies. Attempts to answer the question of retroactivity by avoiding the theoretical inquiry build on shaky foundations indeed.

\section{Equilibrium Analysis; Jill E. Fisch}

In the most recent major scholarly contribution to the literature on retroactivity, Jill Fisch suggests that retroactivity analysis should proceed by reference to a model of legal change that analogizes legal regimes to physical equilibria. Where the existing legal regime is in a stable equilibrium, change should be non-retroactive; where it is unstable, change should be retroactive. ${ }^{189}$

Fisch's article is a work of great sophistication, and its analysis and critique of the existing retroactivity jurisprudence display deep insight. As an answer to the question of retroactivity, her equilibrium theory certainly uses the right factors - notice, reliance, efficiency, etc.-and arrays them in an interesting way. ${ }^{190}$ But like Fallon and Meltzer, she does not imbed her analysis of legal change in an account of how it is that courts change the law-what exactly goes on when a decision is "applied retroactively" (or not). Consequently, the mechanisms for implementing Fisch's desired reforms, and also some of their effects, are not investigated. The injunction to avoid retroactivity in disruptions of stable equilibria presumably requires pure prospectivity-a decision that does not apply the new rule even to the litigants in the law-changing case. Whether this is permissible for Article III courts - and I will argue that on the transaction-time model it is not-is left largely unexamined. ${ }^{191}$ There are difficulties Fisch does not grapple with; her proposals work within the transaction-time model and hence cannot escape its problems. The following part examines those problems in detail and offers an alternative way of thinking about retroac-

189. See Fisch, supra note 1, at $1100-01$. A stable equilibrium is one that returns to the same state after a disturbance; an unstable equilibrium will instead end in a different equilibrium state if disturbed. Fisch uses the example of a coin, in stable equilibrium on either face, in unstable equilibrium on edge. In the legal context, the stable/unstable distinction appears roughly to correspond to the distinction between settled and unsettled law.

190. The metaphor of equilibrium, however, is of limited utility, since it is just as hard to apply as the concepts it is to replace. The superiority of equilibrium analysis to one that works in terms of settled or unsettled law is not obvious. Similarly, Fisch suggests that non-retroactivity is appropriate for changes to stable equilibria, but admits that retroactivity may be appropriate for small changes. See id. at 1105-07. This is not much more helpful than a "clear break" analysis, except that it gives a rather sharper statement of the proposition that there can be no clear break with unsettled law.

191. Fisch does undertake a brief inquiry into constitutional limits on non-retroactivity. She finds few and does not specifically address the advisory opinion issue. See id at 1073-84. 
tivity questions.

\section{THE PROBLEM OF RETROACTIVITY}

The question of retroactivity has proved exceedingly difficult to answer. While the scholarship discussed in the preceding section has offered clever approaches and useful suggestions, it is not fully satisfactory because it does not grapple with the underlying conceptual difficulty. This underlying difficulty is not simply the question of what types of legal change exist; Jill Fisch's analysis of different kinds of equilibrium and transitions from one state to another is a more than adequate taxonomy. The key conceptual issue is rather how legal change is effected: what goes on when a court changes the law. Analysis of this issue is essential because policy prescriptions that are not based on an understanding of how courts change the law risk either incoherence, like Fallon and Meltzer's advocacy of selective prospectivity, or unconstitutionality, like Fisch's suggestion of pure prospectivity. The problem of retroactivity lies in the conceptual structure that baffles these policy prescriptions. That structure is the analytical framework I have been calling the transaction-time model. As long as the Court continues to decide retroactivity questions within this model, satisfactory answers are impossible; if the model is abandoned, the questions are not answered so much as dissolved.

\section{A. The Structure of Retroactivity Analysis: The Problem Discovered}

The problem of retroactivity, as preceding sections have claimed, is rooted in the Court's adherence to the transaction-time model. The task of this section is to show how the model gives rise to the intractable difficulties of retroactivity analysis, and to offer some suggestions as to why we have arrived at such a theoretical impasse.

\section{The Transaction-Time Model and Its Discontents}

Since the transaction-time model is the focus of this section, I will start by taking a moment to recapitulate and give a slightly more detailed exposition of its operation. Recall that the transaction-time model starts from the premise that parties should be judged by the law in effect at the time of their actions. If the decision-time result is to be reached, it must be because decision-time law is also transaction-time law, i.e., because the new law is effective retroactively. The transaction-time model thus offers two options to a court deciding whether to apply a new rule retroactively. The court may apply the rule retroactively, thus changing the law in effect at the time of the relevant transaction. It may also announce that the new rule is to have only prospective effect: it will apply only to cases filed after 
the date of the law-changing decision.

What are the consequences of these dispositions? Retroactive application of new law, as mentioned earlier, changes the law that was in effect at the time of the parties' actions. Lower court decisions applying the old law to transactions occurring after the law-changing decision ${ }^{192}$ are rendered incorrect and must be reversed on appeal. Final decisions dealing with transactions after the law-changing decision, likewise, are made incorrect; the law they applied is wrong-and is made wrong even in the past. $^{193}$

Prospective application obviously does not change the law in the past. Thus it does not inject error into concluded proceedings. A court that holds a new rule prospective does not require it to be applied to past transactions; it does not apply it even to the transaction in the case before it. The new rule that it announces is not the law governing the parties' transaction; it is the law that will be applied to transactions occurring after the law-changing decision.

This conceptual framework creates two interconnected difficulties. First, prospective decisionmaking is unconstitutional. That prospective decisionmaking is not appropriate for the judiciary has been suggested before; ${ }^{194}$ the above analysis should show why. Jurisdiction is the power to say what the law is. Federal courts have jurisdiction only over cases and controversies; they may say what the law is only as an incident to resolving disputes between actual litigants. If this means anything, it means that federal courts may only say what the governing law is, the law that applies to the litigants before them. Prospective decisionmaking clearly goes beyond this function; as Justice Cardozo put it, a prospective decision is merely a "prophecy . . . that transactions arising in the future will be governed by a different rule." It is a paradigmatic advisory opinion. Of

192. Of course, the relevant time should be the date of the transaction in the law-changing case, but Linkletler rejects this approach. See supra note 83 and accompanying text

193. This possibility creates two distinct senses of the phrase "wrong when decided." From the perspective of the court deciding this intermediate case, its decision is correct as a matter of the settled law at the time of the decision-not "wrong when decided," But from the later perspective of the Supreme Court, having held the law-changing decision retroactive, the intermediate case is wrong as a matter of the law at the time it was decided, since the holding of retroactivity changes the law in the past.

The two senses are not always distinguished, and do not need to be except where retroactivity is at issue. I will be using the latter, the criterion of correctness from the perspective of the later Court. A simple way to understand this sense is to suppose that decisions are pegged to the body of law existing when they were rendered. According to the transaction-time model, changes in law that have retroactive effect make pegged earlier decisions wrong. From the perspective of later courts, they are wrong when decided and should be reversed if possible.

194. See, e.g., James B. Beam Distilling Co. v, Georgia, 501 U.S 529, 548-49 (1991) (Scalia, J, concurring).

195. Great Northem Ry. Co, v. Sunburst Oil \& Refining Co., 287 U.S. 358, 366 (1932). 
course it is also something more than that, since it creates the rule it predicts will apply. This transparent lawmaking function has been one of the bases for criticism of prospective decisionmaking, but its advisory character is a sufficient flaw from the perspective of Article III. On the transaction-time model, federal courts cannot engage in prospective decisionmaking.

This fact was recognized by the Stovall Court, though in slightly different terms; ${ }^{196}$ it was the looming threat of advisory opinions that drove the Court to rule that law-changing decisions must be applied to the parties to that case. On the current Court, even the Justices most enamored with prospectivity have conceded that new rules must be applied in the case that announces them..$^{197}$

Once that is done, however, the full rigidity of the transaction-time model becomes apparent. Applying the new law to the parties in the lawchanging decision changes the law as of the date of that transaction. Cases coming up on direct review that feature later transactions must be treated similarly; there is simply no way to distinguish them. ${ }^{198}$

Worse follows. The single retroactive application has also changed the law applicable to cases already finally decided. If the decisions may be collaterally attacked, there is error for which to attack them. Without a distinction between old law and new law - and this distinction is precisely what the transaction-time model eliminates - there is no way to avoid judging collateral attacks according to the new law, for the holding of retroactivity has made it the old law. The obvious incoherence of the position that law differs according to the procedural posture of a case may have been one of the factors driving the Stovall Court to abandon the distinction between direct and collateral review. Yet selective prospectivity does not resolve the underlying difficulty, since applying the new rule retroactively in even one case has the effect of changing transaction-time law. ${ }^{199}$ The transaction-time model simply cannot accommodate a distinction between direct and collateral review. The Court has been reluctant to

196. Stovall characterized the danger as the prospect that constitutional adjudications might "stand as mere dictum" but noted that this concern was "rooted in the command of Article III . . that we resolve issues solely in concrete cases or controversies." Stovall v. Denno, 385 U.S. 293, 301 (1967).

197. See Goodman v Lukens Steel Co., 482 U.S. 656, 689-90 (1987) (O'Connor, J., concurring) Justice Kennedy is O'Connor's staunchest ally in the fight for prospectivity-a fight that as this section shows, is unwinnable within the transaction-time model.

198. Consequently, Justices looking to minimize the retroactive effect of law-changing decisions would do well to shop for cases featuring recent transactions. This itself seems somewhat inconsistent with the judicial role, but it is at least conceptually coherent.

199. See Beam, 501 U.S. at 543 ("Once retroactive application is chosen for any assertedly new rule, it is chosen for all others who might seek its prospective application."). 
face this fact, preferring to rely on an untenable distinction, ${ }^{200}$ but the problem cannot be denied. (Indeed, as the next section shows, the Court has had to struggle not to admit this consequence of the transaction-time model and has been only partly successful at keeping it out of the caselaw.)

Teague is a solution, but not a happy one, and indeed it is symptomatic of a larger mistake. In analyzing the difficulties created by the interaction of retroactivity and collateral attack, both the Court and commentators have persistently seen habeas, rather than retroactivity, as the source of the problem. ${ }^{201}$ They have thus responded by tinkering with habeas - and this confusion has also infected the legislative process. An obvious way to prevent the feared avalanche of habeas petitions based on new law is to impose a time limit, or other restrictions, on habeas petitions. This has been done with the Anti-Terrorism and Effective Death Penalty Act of 1996 ("AEDPA"). ${ }^{203}$

The AEDPA requires petitioners bringing a second or successive habeas petition to obtain certification from a court of appeals that the petition contains newly discovered evidence establishing innocence, or a new rule of constitutional law the Supreme Court has "made retroactive to cases on collateral review." ${ }^{205}$ It also imposes a one-year limitations period, which begins to run anew if the Supreme Court announces a new rule of constitutional law and holds it applicable retroactively to cases on collateral review.

The AEDPA is a clear example of the shortcomings of trying to fix a retroactivity problem by modifying habeas. When combined with the transaction-time model, it reaches results that verge on unconstitutionality in some contexts. Specifically, by allowing new petitions to be based only on new constitutional rules, it denies relief to actually innocent prisoners. Here again, positive source is important, since it provides an intuitive augmentation of the meaning of retroactive application. In statutory interpretation, I have said, the impulse to adjudicative retroactivity is strongest. The law does not change, although interpretations do. When the Supreme

200. See Teague v Lane; 489 U.S 288 (1989). Finality is the interest usually invoked to distinguish between direct and collateral review. The principle of finality does draw a line, but not the one desired, for finaiity gives us no reason to distinguish between collateral attacks based on new law and those based on old law: See Griffith v. Kentucky, 479 U.S. 314, $332 \mathrm{n} .1$ (1987) (White, J., dissenting) (arguing that finality fails to distinguish between cases on direct and collateral review).

201. See, e.g. Williams v. United States, 401 US. 667. 701-02 (1971) (Harlan, J., concurring): Haddad, supra note 64, at 1076-78, Meador, supra note 165. Haddad, ironically, criticizes the Court for changing retroactivity doctrine in order to reshape habeas sub rosa. Changing retroactivity doctrine to eliminate the trouble with habeas is precisely what should be done.

202. Pub. L. No. 104-132, 110 Stat, 1214 (1996).

203. 28 U.S.C. \$ 2255 (1994 \& Supp. II 1996) 
Court overrules a lower court's interpretation of a statute, it is hard to argue that people convicted under the rejected interpretation are not entitled to the benefit of the new ruling - it is hard to argue that the lower court's interpretation was not simply wrong. Thus in statutory interpretation cases, the AEDPA seems to bar relief for people who are clearly entitled to it, who were convicted and sentenced for conduct that is not now and never was a crime.

This conundrum emerged with particular clarity in the wake of the Supreme Court's decision in Bailey v. United States. ${ }^{204}$ Bailey interpreted 18 U.S.C. $\S 924(\mathrm{c})$, which imposes a five-year sentence on anyone who "uses or carries" a firearm "during and in relation to any crime of violence or drug trafficking crime." Bailey read "uses" to contain a requirement of active employment; it was not enough for a Section 924(c) conviction that the weapon was available for use. ${ }^{205}$ And it did so retroactively; it applied the decision to Bailey himself. The consequence is that people convicted for merely having a weapon available are clearly innocent. Yet because Bailey is a case involving statutory interpretation, not the required new rule of constitutional law, the AEDPA appears to prevent them from bringing a petition under 28 U.S.C. $\$ 2255$, the habeas counterpart for federal prisoners.

Courts that have confronted this problem have reacted with fancy judicial footwork, typically finding that the inadequacy of Section 2255 relief entitles federal prisoners to the unusual avenue of habeas. ${ }^{206}$ Their creative responses only highlight the fact that the statute is malfunctioning, that attempting to solve retroactivity problems through habeas reform is a serious mistake. And the problem that Teague and the AEDPA address is quite clearly a consequence of retroactivity, not of habeas. The scope of issues cognizable on habeas may be set as broadly as those cognizable on appeal; petitions relying on changes in law will still pose no threat to the administration of justice if they are judged by the law in effect at the time of their trials. ${ }^{207}$ How to do this consistently while applying new law to cases on direct review is the overwhelming question of retroactivity jurisprudence, and I will answer it later. For now, the point is only that it cannot be done within the transaction-time model, and tinkering with habeas does not help.

204. 516 U.S. 137 (1995).

205. See id at 150

206. See, eg., Triestman v. United States, 124 F.3d 361 (2d Cir. 1997): In re Dorsainville, 119 F $3 d$ 245 (3d Cir. 1997).

207. There are, of course, those who want to restrict habeas for other reasons. But the troubled interaction between habeas and retroactivity clearly starts with the Warren Courn's changes in law, and clearly stems from the difficulties in distinguishing direct from collateral review. 
The embarrassment of selective prospectivity, and the Court's convoluted history of attempts to distinguish between direct and collateral review, are both products of the theoretical framework it has chosen. If it causes such difficulties, one must wonder why the Court did choose it. The next section offers a possible explanation. ${ }^{208}$

\section{Origins of the Transaction-Time Model}

The premise of the transaction-time model - that parties should be judged by the legal standards in effect at the time of their actions-has some obvious attractions. Basic concepts of notice and reliance suggest that it is unfair to judge parties according to law of which they could not have known. These concerns have substantial intuitive appeal and feature prominently in the case law. ${ }^{209}$

However, as subsequent sections will show, there are other ways to give normative weight to notice and reliance. Choice of the transactiontime model may be motivated in the first instance not so much by a concern for protecting expectations as by the "discretionary" conception of judicial lawmaking. This conception is one in which hard cases confront judges with substantial indeterminacy. With no right answer available, judges must effectively legislate new rules as a matter of discretion.

On this understanding, law-changing decisions create new rights and duties. Applying new rules to parties who acted in good faith reliance on the law that governed at the time of their actions is simply unjustifiable. ${ }^{210}$ "Retroactive effect," meaning reaching the decision-time result, must be justified by retroactivity, meaning changing transaction-time law. ${ }^{211}$ The transaction-time model sees judicial lawmaking as akin to legislative, ${ }^{213}$

208. Since this explanation sees the adoption of the transaction-time model as the consequence of a misunderstanding, it is of course only tentative. It is certainly presumptuous and perhaps impossible to pinpoint exactly what was misunderstood.

209. See, e.g, Chevron Oil Co. v. Huson, 404 U.S. 97, 106-07 (1971) (noting the possible inequitable results of applying law retroactively).

210. See, e.g, DWORKIN, supra note 23 , at 85 (agreeing that "it wouid be wrong to sacrifice the rights of an innocent man in the name of some new duty created after the event").

211. The justification afforded by retroactive alteration of transaction-time law is obviously purely metaphysical in nature. It offers cold comfort to parties who relied on old law with the expectation that it would not be changed. The jurisprudential underpinnings of the transaction-time model, for those sensitive to this unfaimess, thus lead naturally to a very limited use of retroactivity. The most limited use would be retroactive application only in the case announcing the new rule. Tha: is selective prospectivity, and it is indeed where the transaction-time model led the Warren Court, in Stovall v Denno, 388 U.S. 293 (1967).

212. Thus the current dominance of the transaction-time model may be a contingent consequence of the historical fact that modern retroactivity jurisprudence begins with the law-changing criminal procedure decisions of the Warren Court, which are most easily understood as legislative-style changes in law. The disruptive consequences of retroactively imposing new requirements on the 
and applies to it the same presumption of non-retroactive effect. ${ }^{213}$

As an explanation of the Linkletter Court's reasoning, however, the assimilation of judicial to legislative lawmaking is too pat to be believed. It is ironic that the Warren Court, under heavy criticism for the sin of "judicial legislation," adopted an analytical framework that admits to precisely that; it may even be revelatory to legal psychoanalysts who believe in the telling judicial parapraxis. But a recognition that its new rules were not compelled by precedent $t^{214}$ cannot have been the conscious motivation of the Linkletter Court; it had, after all, already applied Mapp to cases pending on direct review, and pure prospectivity would be the normal treatment for legislative-style change.

The real explanation for Linkletter's turn to the transaction-time model is most likely that the Court, having dramatically reshaped constitutional criminal procedure, was looking for help in rejecting collateral attacks based on new law. What this required, since the Court had already applied Mapp to cases on direct review, was a way of distinguishing between direct and collateral review. It is in the quest for this distinction that modern retroactivity jurisprudence is born. Linkletter invoked the transaction-time model, most likely, because it succumbed to the delusion that a distinction between direct and collateral review may be drawn only by an approach that commits itself to the general proposition that courts should apply the law in effect at the time of the relevant transaction. Such an approach does suggest that old law should govern old transactions, and it is to lend jurisprudential authority to this proposition that Linkletter sets up Blackstone and knocks him down with Austin. But the approach does not distinguish between direct and collateral review, a fact that seems simply to have escaped the Linkletter Court.

From this perspective, Linkletter appears equal parts comedy and tragedy. The truth is that the desired distinction can in fact be made only within the model of retroactivity analysis that the Linkletter Court abandoned, the model that had prevented the question of retroactivity from becoming a problem for the fifty years or so that intervened between the

states, coupled with the impossibility of dampening these consequences via remedial analysis, led the Court to seek prospective results within the transaction-time model.

213. The "presumption" that I refer to is theoretical and imbedded in the model Absent retroactivity, transaction-time results are proper. This does not mean that the transaction-time model, as employed by the Court, tends to produce those results; the possibility of retroactivity means that application of transaction-time law can still produce decision-time results. Although the Warren Court often reached transaction-time results, subsequent Courts, working largely within the same model, have changed direction so drastically as to make decision-time results the norm.

214. See Linkletter v. Walker 381 U.S. 618, 630 (1965) ("IT] he federal exclusionary rule was not derived from the explicit requirements of the Fourth Amendment .... The decision was a matter of judicial implication." ) (quoting Wolf v. Colorado, 338 U.S. 25, 28 (1949)) 
death of the Blackstonian understanding and the Warren Court's reworking of retroactivity. This model, and the solutions it offers, are the subject of the next section.

\section{B. Eliminating Retroactivity: The Problem Solved}

The transaction-time model has dealt courts two difficulties: it makes pure prospectivity unconstitutional, and it creates real problems with collateral review. The first is not so major; more importantly, it is unavoidable. A purely prospective decision is advisory no matter how one looks at it. The second is more serious; it is what drove retroactivity doctrine on its erratic course between Linkletter and Teague, and it is still with us, as the troubling new issues created by the AEDPA show. The solution lies in understanding why the problem used to be a non-issue, why retroactivity was not a difficult question until Linkletter.

\section{The Dog That Didn't Bark and the Decision-Time Model}

Until the 1960s, the question of retroactivity was a dog that did not bark. Like that of its famous Holmes ${ }^{215}$ counterpart, its silence tells us something important. Admittedly, until the dramatic innovations of the Warren Court, the question did not have the same degree of importance. But the issue existed; it is clearly present in cases such as Carpenter v. Wabash Railway Co. ${ }^{2 ! 6}$ and Chicot County Drainage District v. Baxter State Bank. ${ }^{217}$ What distinguishes the smooth analysis of those cases from the Warren Court's lugubrious flailings is that they did not employ the transaction-time model, nor even the concept of retroactivity. They simply followed the general rule that a court must decide the cases before it according to the best current understanding of the law. ${ }^{2 ! 8}$

This principle is the keystone of the alternate conceptual approach to retroactivity analysis, what I call the "decision-time model." Where the transaction-time model supposes that the legally relevant rights and duties are those existing at the time of the parties' actions, the decision-time model starts from the opposite premise. Courts should apply their current best understanding of the law to all cases before them, regardless of whether the best understanding at the time of the transaction would produce a different result.

215. Sherlock, not Oliver Wendell ir. See SIR ARTHUR CONAN DOYLE. THe CONPLETE ORIGINAL ILLUSTRATED SHERLOCK HOLMES (SILVER BLAZE) 117 (1976).

216309 U.S. 23, 27 (1940) (explaining that if a law intervenes and changes the governing rule after the judgment and before appellate review, appellate court must obey new law).

217. 308 U.S. $371,374-75$ (1940) (refusing to upset a judgment based on a subsequent change in the law).

218. See, e.g., Chicot, 308 U.S. at 377 
A Court confronted with a "retroactivity question" thus has no choice in what law to apply if it is using the decision-time model. Current law governs, and the authority of a law-changing decision cannot be denied. Like the transaction-time model, however, the decision-time model can usually reach either result in terms of who wins the case.

Producing the transaction-time result requires some work and may not always be possible. In many cases, however, use of the law of remedies will permit it. Suppose that the law-changing decision adopts a different statute of limitations, and that the injured party brings his suit before the expiration of the statute of limitations prevailing at the time he files. The suit may be time-barred under the new statute of limitations, but timely under the old. A court troubled by the unfairness of denying relief to an injured party based on new law might nonetheless allow the suit to proceed by equitably tolling the new statute of limitations. ${ }^{219}$ Despite applying decision-time law, the court can nonetheless reach the transaction-time result. Reaching the decision-time result is more straightforward. Without any discussion of retroactivity, the Court simply applies the current law. ${ }^{220}$

The significant advantage of the decision-time model emerges when it is realized that this approach has no effect on the earlier law. While the transaction-time model requires a court to alter transaction-time law in order to achieve retroactive effect, the decision-time model does not. Earlier decisions, pegged to their contemporaneous law, are consequently correct, although they will not be followed.

\section{Why the Decision Time-Model?}

Like the transaction-time model, the decision-time model is linked to a particular conception of judicial decisionmaking, and a choice of the decision-time model may be motivated in part by a different understanding of the judicial role. The province of the judiciary is to say what the law is, not what it was; one can maintain a priori that it is the duty of judges to

219. This approach was rejected in Lampf, Pleva. Lipkind, Prupis \& Petigrow v. Gilbertson, $50 !$ US 350,361 (1991), and seems never to have been adopted by a majority of the Court. At different times, however, a number of Justices have commented that the question of what law applies should be distinguished from the question of what remedy may be granted. See, e.g. Harper v. Virginia Dep't of Taxation, 509 U.S, 86, 131-34 (1993) (O'Connor, J., dissenting) (pointing out that applying the rule retroactively is a separate question from the remedy to be given); James B. Beam Distilling Co. $v$. Georgia. 501 U.S. 529, 534-35 (1991) (distinguishing the issue of applying a law forward or backward from determining remedies): United States y. Estate of Donnelly, 397 U.S. 286, 297 (1970) (Harlan, J, concurring) (noting that the flexibility in the law of remedies does not affect the fact that generally courts should apply the prevailing rule)

220. For an example of this approach, see Lampf, 501 U.S. at 361 
decide cases based on their best understanding of the law, ${ }^{2.21}$ However, the decision-time model may draw its attractiveness largely from the "right answer" conception of judicial lawmaking. This conception, naturally enough, is diametrically opposed to the one motivating the transactiontime model. On this understanding, judicial lawmaking, while it may change results, reaches the right answer to the particular legal question posed. $^{222}$ Applying decision-time law on the "right answer" conception is simply reaching the just result in the case at hand. ${ }^{223}$ Concerns of notice and reliance may have weight within this model, ${ }^{224}$ but they must be taken into account in a remedial calculus. ${ }^{225}$

The "right answer" and the "discretionary" theories are competing visions of judicial decisionmaking. They can be loosely linked, respectively, to natural law and positivist theories. ${ }^{226}$ If the content of "law" is extended to include broad moral and political principles, then it is obviously easier to maintain that judicial decisions reach the right answer; if

221. See Mackey v. United States, 401 U.S. 667, 681 (1971) (Harlan, J, concurring).

222. See Beam, 501 U.S. at 549 (Scalia, J., concurring) (stating that judges make law "as though they were "finding it -discerning what the law is, rather than decreeing what it is today changed to"); DWORKIN, supra note 23, at 81-87. Dworkin's views have evolved over the years, and his more recent work seems to place less emphasis on the principle that adjudication simply enforces preexisting legal rights. See DWORKIN, supra note 177, at 225 ("So law as integrity rejects as unhelpful the ancient question whether judges find or invent law; we understand legal reasoning, it suggests, only by seeing the sense in which they do both and neither.").

223. See Desist v. United States, 394 U.S. 244, 259 (1969) (Harlan, J., dissenting) ("Nonretroactivity] would belie the truism that it is the task of this Court, like that of any other, to do justice to each litigant on the merits of his own case ").

224. See, e.g., United States v. The Schooner Peggy, 5 U.S. (1 Cranch) 103, 110 (1801) (noting that the court should consider the effect on parties when applying law retroactively in certain cases).

225. Greater focus on remedial discretion would certainly benefit retroactivity jurisprudence, as Fallon and Meltzer and others have argued. See, e.g, Fallon \& Meltzer, supra note 42; Note, Retroactivity and the Exclusionary Rule: A Unifying Approach, 97 HARV. L. REV. 961 (1984) (analyzing the retroactivity of Fourth Amendment decisions). Even on the transaction-time model, remedial adjustments are possible following a conclusion that decision-time law is to be applied retroactively. See, e.g., Beam, 501 U.S. at 535 (applying a law retroactively may affect the remedy given). This route to the remedial calculus is somewhat circuitous, but if there were any reasons for favoring the transaction-time model, it might have been desirable.

226. In particular, my discussion of the decision-time model prominently features a notion akin to Ronald Dworkin's "right answer" thesis. See DworkiN, supra note 23, at 87, 279-80; see also DwokkiN. supra note 177, at 266-71. The concept of legal indeterminacy requiring judicial discretion relates similarly to H.L.A. Hart's positivist theory. See H.LA. HART. THE CONCEPT OF LAW 244-54 ( $2 \mathrm{~d}$ ed. 1994). However, the connections between the legal philosophies and the models are weaker than they may seem at first glance. Dworkin's ideas appear on both sides; the transactiontime model is produced by conjoining Dworkin's "rights thesis," see DwORKIN, supra note 23, at 82 90 , with a positivist/realist account of law-changing decisions. (A not entirely happy marriage, to be sure.) Dworkin himself argues for the enforcement of transaction-time law as a matter of principle but seems to suppose that the correct decision-time answer is the same. This neo-Blackstonian approach, as discussed earlier, elides the question of what happens when law changes between transaction and decision. 
"law" is more narrowly construed, it appears that judicial decisionmaking is more often discretionary. These linkages invite more exploration, but I hope to avoid the quagmire of jurisprudence..$^{227}$ My purpose is emphatically not to argue for the adoption of one or the other model on the basis of its philosophical pedigree.

Moreover, the successive embrace of non-retroactivity by the Warren and Burger Courts shows that results, in the sense of retroactivity or nonretroactivity, are not tied to political programs; nor, a fortiori, are models. Because political valence changes over time, ${ }^{228}$ a theoretical investigation of retroactivity should be able also to avoid the ideological thicket. My aspiration is merely to achieve a perspicuous rendering of the theoretical structure of retroactivity analysis and a prescription for enhanced clarity and coherence. The two models differ in their abilities to reach particular results; consequently, there are good reasons to select the one that allows our current regime to be presented as a body of doctrine formed by consistent application of principles rather than one that is internally contradictory and relies on unjustifiable distinctions.

In particular, as mentioned above, the decision-time model allows courts to apply a change in the law to cases pending on direct review without creating error in concluded proceedings. The problem of collateral attack does not arise; the decision-time model distinguishes between direct and collateral review.

The mechanics of the distinction are fairly straightforward. On direct review, an appellate court re-examines contested issues according to the best current understanding of the law. Thus, affirmance on direct review calls for repetition: An affirmed decision has the authority of the affirming court behind it.

Collateral review works differently. For a decision to survive collateral review, the reviewing court must assert not that the result would be the same if the case were litigated at the time of the collateral attack, but merely that the decision was correct when rendered. Of course, this principle is seldom apparent in civil cases. Res judicata ordinarily prevents relitigation of claims, and it will shield even a decision that was wrong

227. The debate over whether law is "made" or "found," which corresponds roughiy to my discretionary/right answer models of judicial lawmaking. is interesting from a metaphysical perspective but not very useful. Neither account is especially plausible as a description of all, or even the essence of, judicial decisions. Judging is a craft, its instances are related not by derivation from a platonic universal but by a family resemblance. See POSNER, supra note 8, at 226. My prescriptive claim is that disparate types of judicial lawmaking nonetheless require a unified retroactivity analysis, in order to produce stable and coherent doctrine. Thus, what is essential is to select a particular analytical framework rather than wandering in the metapinysical desert.

228 See I.M. Balkin, Ideological Drift and the Struggle Over Meaning, 25 CONN. L. REV. 869 (1993). 
when rendered. Importantly, however, the principle does operate in cases where the issue is whether res judicata is available as a defense; it is this fact that allows us to discern the nature of collateral review. ${ }^{229}$

In criminal cases, where the writ of habeas corpus allows for broader collateral challenges, the nature of collateral review obviously assumes greater importance. The availability of habeas is not restricted by the ordinary rules of res judicata, and relitigation of issues is permitted. ${ }^{230} \mathrm{Ha}$ beas is, nonetheless, a collateral remedy, focusing on the correctness of the judgment when rendered. For example, repeal of a criminal law, which clearly bars future prosecutions and abates those for which appeal is pending, ${ }^{231}$ does not provide grounds for a habeas petition. ${ }^{232}$ A change in law, on the decision-time model, has no effect on the soundness of an earlier judgment; a decision-time result on direct review does not alter the law applicable to a habeas petitioner. ${ }^{233}$ It is only the transaction-time

229. As Justice Harlan pointed out in Mackey v. United States, 401 U.S. 667. 698 (1971) (Harlan, $\mathrm{J}$, concurring), Chicot was such a case and employed precisely the analysis I advocate. Chicot featured an attempt to attack collateraily a plan of debt readjustment issued by a district court pursuant to a statute later held unconstitutional. See Chicot County Drainage Dist. v. Baxter State Bank, 308 U.S. $371.373-74$ (1940), Res judicata prevents parties from relitigating issues that were or could have been raised in an earlier proceeding, with an exception for void judgments. Lack of subject-matter jurisdiction renders a judgment void, so if the statute providing jurisdiction is unconstitutional, res judicata cannot be raised as a defense. The Chicot Court allowed the res judicata defense based on the proposition that the statute granting jurisdiction to the district court was constitutional at the time of the debt readjustment, having been so adjudged by that court. See id at 377-78. This treatment of collateral review is the direct analog to the argument this Article makes about the consequences of the decision-lime model for habeas. Using the decision-time model, a court engaged in collateral review need concern itself only with the question of whether the challenged decision was right when rendered. A similar approach was followed in Cipriano v City of Houma, 395 U.S. 701, 706 (1969) (applying approach to Louisiana law giving right to vote only to "property taxpayers").

230. See FALLON ET AL, supra note 118 , at 1345.

231. See, e.g, United States y. Chambers, 291 U.S. 217,223 (1934) (holding that cases pending for violations of the National Prohibition Act could not be continued when the Eighteenth Amendment was repealed). Legislatures may, of course, provide by savings clauses that pending prosecutions are to continue despite repeal. See, e.g., 1 U.S.C. \$109 (1994).

232. See, e,g., Welch $v$, Hudspeth. 132 F, 2d 434, 436 ( 10 th $\mathrm{Cir}$, 1942) (denying collateral relief to peritioner whose conviction became final before repeal of Prohibition). As I argue below, an exception exists for petitioners whose conduct is held constitutionally protected after their convictions become final. The repeal of Prohibition does not, of course, qualify for this exception because the Twenty-first Amendment did not recognize a constitutional right to manufacture or sell liquor.

233. The prevailing drift of scholarship on this point, interestingly, seems to run in directly the opposite direction, arguing that even non-retroactive application of law-changing decisions should allow habeas petitioners to benefit. See, e.g., Meador, supra note 165, Meador starts from the premise that imprisonment is an ongoing sanction--which is clearly true-and contends that "the situation is as though the warden appeared at the prisoner's cell every moming bearing the illegally seized evidence in his hands, thereby using it to keep the prisoner in confinement for another day" 1d. at 1117 . That this conclusion simply cannot be correct can be seen by imagining a change in Federal Rules of Criminal Procedure-requiring, for example, yellow paper where before green was required. We cannot say, in adjudging a petition under 28 U.S.C. $\$ 2255$ (1994 \& Supp. II 1996), that 
modeI, with its retroactive creation of error in earlier trials, that allows habeas petitioners the benefit of law-changing decisions. The decisiontime model thus itself makes the distinction between direct and collateral review that so plagued the Warren Court. ${ }^{234}$

This distinction does not mean, of course, that a habeas petitioner can never win relief on the decision-time model. Habeas lies for prisoners held "in violation of the constitution, or of any treaty or law of the United States." 235 Incarceration after a change in law might violate the Constitution in two primary ways - ways which, interestingly enough, precisely track the Harlan/Teague exceptions to non-retroactivity on collateral review.

First, a prisoner seeking the benefit of a new constitutional rule that placed "certain kinds of primary, private individual conduct beyond the power of the criminal law-making authority to proscribe" should be able to argue that his continued imprisonment is unconstitutional, ${ }^{236}$ The argument for this result relies on a distinction between privative sanctions such as fines, which can be remedied only retroactively, and ongoing sanctions such as incarceration, which can be remedied prospectively. Continued punishment requires continuing power to proscribe. If certain conduct is held constitutionally protected, the government loses the ability to punish it, and continued sanctions are imposed only in violation of the Constitution, ${ }^{237}$ Thus collateral attack should be able to win prospective relief

\footnotetext{
"the warden shows up every day bearing the green paper, and now that yellow is required the prisoner must go free." Paper changes, of course, could be dealt with by harmless error analysis, and a stronger point against Meador's argument is the fact that even repeal of the law under which a criminal is imprisoned will not allow collateral attack on the conviction.

234. This is not to say that it makes habeas simple. A court faced with a habeas petition relying on new law must stil decide if the law is actually new - which may depend on its positive source or on more practical considerations. Shorn of the jurisprudential wool that clings to the idea of "new law," this is essentially the question of retroactivity, and as such it is not the concern of the Article. Fisch's equitibrium analysis, or Fallon and Meltzer's approach through remedies, are good examples of attempts to develop rules for deciding that issue; it is work enough for this Article to reach a position in which the decision is possible. See Fallon \& Meltzer, supra note 42; Fisch, supra note 1.
}

235. Judiciary Act of 1867 , ch. $28, \$ 1,14$ Stat $385-86$ (I867).

236. Such seems to be the dominant practice. In United States ex rel. Williams v. Preiser, $360 \mathrm{~F}$. Supp. 667 (S.D.N.Y. 1973), a physician convicted under a state abortion-manslaughter statute won release after the decision in Roe v. Wade, 410 U.S. 113 (1973). See also Robinson y Neil, 409 U.S. $505,510-11$ (1973) (noting that Linkletler analysis is inapplicable to non-procedural rights)

237. See United States v. United States Coin \& Currency, 401 U.S. 715, 726-27 (1971) (Brennan, J., concurring) (stating that "a decision holding certain conduct beyond the power of government to sanction or prohibit must be applied to prevent the continuing imposition of sanctions for conduct engaged in before the date of that decision"). This proposition seems undeniable; it is hard to imagine, as Brennan goes on to note, that Virginia might keep in jail interracial couples who had cohabited within the state before Loving v, Virginia, 388 U S. I (1967). See United States Coin, 401 U.S at 728 . Uniled States Coin in fact went further: it allowed privative sanctions (forfeitures) to be undone although the law authorizing them had been upheld by the Supreme Court sixteen years 
based on a change in constitutional law. Incarceration, like injunction, operates in futuro; the soundness of continued imprisonment should be analyzed under the law at the time of the challenge. ${ }^{238}$ Imprisonment for conduct that is constitutionally protected is a constitutional violation regardless of how sound the trial or how new the right.

Teague's second exception, for challenges to procedures that both violate fundamental fairness and relate to the accuracy of the trial, is not quite so clearly a consequence of the decision-time model. Whether it is or not depends on our understanding of due process. In an influential article, Paul Mishkin suggested that due process requirements going to the accuracy of a verdict represent a constitutional guarantee that no one shall be imprisoned except upon a showing of guilt with a certain required degree of probability. ${ }^{239}$ This is functionally true, and makes good sense as theory. And it follows, on this view, that habeas petitioners get the benefit of new rules of constitutional law relating to the accuracy of the trial. Their convictions may have been sound, but the constitutional guarantee does not only bar new convictions. It requires the States to justify imprisonment by a particular showing, and if that showing has not been made, imprisonment cannot contimue. Once again, the ongoing nature of the sanction and the availability of prospective relief make all the difference.

The preservation of this exception may be of only minor consequence, since the Court has yet to announce a new such "component[] of basic due process $^{, 240}$ and has indicated substantial doubt that any exist undiscovered. ${ }^{2+1}$ Regardless, judging collateral attacks in general, and habeas petitions in particular, by the law prevailing at the time of the

earlier against the Fifth Amendment challenge that prevailed in United States Coin. See id. at 722; see also Lewis v. United States, 348 U.S. 419 (1955). This stronger position is unsound, and it won the support of only four Justices.

238. See American Steel Foundries V. Tri-City Central Trades Council, 257 U.S. 184, 201 (1921) (stating that "because relief by injunction operates in futuro, .... the right to it must be determined as of the time of the hearing"), FED. R. CIV. P. 60(b)(5) (providing for reevaluation of injunctions in light of changed circumstances). Evaluating imprisonment under the law obtaining at the time of the chaltenge does not, of course, mean that repeal of criminal laws should allow collateral attack on convictions on that basis. See Welch v Hudspeth, 132 F.2d 434, 436 (10th Cir, 1942) (denying collateral relief to petitioner whose conviction became final before repeal of Prohibition). The government's power to punish conduct is not called into question by repeal of a law. It is only where punishment is constitutionally forbidden that prospective relief should be granted on collateral review.

The question of challenging a repealed statute on the grounds that the once-proscribed conduct is constitutionally protected presents a slightly more difficult issue, also created by statutes held unconstitutional on grounds (e.g., vagueness or overbreadth) that do not suggest that a petitioner's conduct is constitutionally protected. Presumably, justice requires that a petitioner be allowed to raise the argument. despite the fact that the statute is no longer in force.

239. See Mishkin stpra note 76. at 81-82.

240. Teague v Lane, 489 U S, 288, 313 (1989).

241 See id 
original trial seems by far the sounder course. Justice demands no more, and logic no less. Wholesale adoption of the decision-time model could have spared the Court the difficulties it confronted.

In fact, the decision-time model entirely eliminates the theoretical structure that drove the Warren Court to its unsatisfying inconsistencies. It solves the problem of retroactivity. The silence of the question of retroactivity before Linkletter is thus precisely the same as that in Arthur Conan Doyle's Silver Blaze. The dog did not bark because it recognized its master.

When Linkletter introduced the transaction-time model, it did not offer the best possible response to a difficult new problem. It created the problem and offered a plainly inadequate response. I have tried to suggest why it did so; the next question is why the decision-time model did not make its way back. Answering this question does not require quite the same degree of speculation; the model's attempt to do so, and its ultimate failure, are there in the caselaw. The exile of the decision-time model and its unsuccessful return is the hidden story of retroactivity jurisprudence. The next section tells it for the first time.

\section{Why Not the Decision-Time Model? The Secret History of Retroactivity}

Viewing the caselaw with an awareness of the two models produces a picture startlingly different from the received wisdom. The struggle over retroactivity - the vacillation between decision-time and transaction-time result - has been a mask for the deeper conflict between the two models. It has been, in many ways, a proxy war, and while decision-time result has won most of the battles, the decision-time model has lost the hearts and minds of the federal bench. At the level of result, the current embrace of retroactivity has returned us to where we started. But in terms of the models, things are quite different. By rereading the caselaw from this perspective, we may know the place for the first time.

To understand the cases in terms of the dueling models, it is important to be able to ascertain which one a court is employing. Because the distinction between the two has never been explicitly addressed, this is not always easy. A decision that announces that new law will be applied only prospectively is clearly working within the transaction-time model. Harder issues are presented by cases that apply new law retroactively. The decision-time model, by applying new law, produces automatic retroactive effect. It does not, however, rely on the concept of retroactivity to do so, and this fact allows the distinction to be made.

If the decision-time model is adopted, the concept of "retroactivity" 
drops out of the analysis. Decision-time law is applied without retroactively changing transaction-time law, for the simple reason that only decision-time law is relevant. Given this fact, the framing of the issue in terms of retroactivity is itself an indicator of the transaction-time model.

It might seem surprising that this is really a reliable indicator. Surely, one might think, once the Court began to talk about retroactivity, cases presenting the issue used the terminology, and diction ceased to be revelatory. I would agree with this objection if the concept of retroactivity did pervade the case law, if after Linkletter the Supreme Court never achieved retroactive effect without a mention of retroactivity. But the reality is otherwise. Several Justices have urged analyses that do not mention retroactivity, ${ }^{242}$ and several cases have applied new law without discussing the concept. ${ }^{243}$ The decision-time model is there in the caselaw, and its proponents have been remarkably consistent in employing its distinctive vocabulary. Cases that analyze the issue in terms of "retroactivity" are thus best understood as employing a transaction-time model.

The decision-time model also has its indicators. As discussed above, a decision that grants retroactive effect to new law without discussing retroactivity must work within the decision-time model. More obviously, decisions that assert that courts must decide cases based on their best current understanding of the law employ decision-time analysis. A final mark of this approach is the assertion that earlier inconsistent decisions were correct. As noted earlier, the transaction-time model reaches decision-time results by retroactively altering transaction-time law. This creates error in earlier decisions; thus, an opinion that characterizes earlier decisions as correct must employ the decision-time model.

This last indicator is not entirely reliable, given the two different senses of "correct when decided." 244 It does, however, tend to match up well in the caselaw with the indicia considered previously. ${ }^{245}$ Using these criteria, it is possible to identify the model driving the analysis in virtually every case. What emerges is a persistent struggle subject to the vagaries of Court membership and the exigencies of doctrinal change.

The story begins with the demise of the Blackstonian conception of law, which freed the two models to compete. Because the practice under

242, See, e.g, Williams v. United States, 401 U S. 667, 679 (1971) (Harlan, J., dissenting); James B. Beam Distilling Co. v Georgia, 501 U.S. 529, 548-49 (1991) (Scalia, J., concurring).

243. See, e.g., Lampf, Pleva, Liphind, Prupis \& Petigrow v Gilbertson, 501 U.S 350 (1991); Vandenbark v. Owens-11linois Glass Co., 311 U.S. 538 (1941).

244. See supra note 193.

245. For examples of decision-time model cases characterizing earlier decisions as correct, see Vandenbark, 311 U.S. at 543, and United States . The Schooner Peggy, 5 U.S. (1 Cranch) 103, 110 (1801). 
the Blackstonian understanding was to give automatic effect to later statements of the law, the decision-time model had a significant advantage. Already enshrined in Marshall's The Schooner Peggy opinion, it quickly extended its reach to law-changing decisions. Within the decision-time model, the concept of retroactivity plays no role, and Supreme Court decisions through the 1940s, relying heavily on The Schooner Peggy, applied decision-time law without discussion in cases where changes were wrought by intervening legislation ${ }^{246}$ or decisions. ${ }^{147}$ Vamdenbark v. Owens-Illinois Glass Co ${ }^{2+8}$ explicitly repudiated Burgess and Kuhn, holding that federal courts "should conform their orders to the state law as of the time of the entry. Intervening and conflicting decisions will thus cause the reversal of judgments which were correct when entered, ${ }^{1249}$

The conflict began in earnest with Linkletter. That decision planted itself squarely, if ineptly, within the transaction-time model. ${ }^{250}$ But it soon became apparent that Linkletter's grounds were too hot to stand on; with Stovall the Court began a frenetic dance, protecting one part of its sensitive jurisprudence only to expose another to the fire of criticism ${ }^{25 i}$ From the beginning, the transaction-time model was beset with difficulty, as the Court tried to draw lines that its own theory erased. Justice White's Engle-Hankerson approach to habeas petitions offered the possibility of achieving different results for collateral and direct review within the transaction-time framework. Had the Court followed this line of reasoning (and abandoned selective prospectivity in favor of uniformly retroactive result on direct appeal), it would have done the best it could with the tools at hand, and a stable body of doctrine might have resulted. The opinions

246. See, e.g., Carpenter v. Wabash Ry. Co, 309 U,S, 23 (1940). Carpenter, like The Schooner Peggy, is best understood as standing for decision-time iaw rather than decision-time result. The statute at issue explicitly provided for application to cases "now. . pending in any court of the United States." Id. at 27 (quoting Bankruptcy Act, 53 Stat. 1406 (1939) (codified at 11 U.S.C \$ 205(n)) (repealed 1978)).

247. See, e.g. Vandenbark, 311 U.S, at 538 .

248. See id.

249. Id. at 543

250. That the decision-time model was the existing baseline that Linkletter disturbed can be seen from the fact where the issue was retroactive legislation, which Linkletter did not discuss, the decision-time model persisted in a line of cases relying on The Schooner Peggy, and running through Thorpe v. Housing Authority of Durham, 393 U.S. 268, 281 (1969), up to Bradley v. School Board of Richmond, 416 U.S. 696, 711 (1974). Bradley is illustrative: "We anchor our holding in this case on the principle that a court is to apply the law in effect at the time it renders its decision . "Id. This line effectively came to an end when the Supreme Court reevaluated legislative retroactivity in Landgraf v. USI Film Prods., 511 U.S. 244 (1994).

251. Colorful metaphors for the Court's wild retroactivity jurisprudence are not uncommon. See, e.g. Williams v. United States, 401 U.S. 667.676 (1971) (Harlan, J, dissenting) (lamenting that the course of the Linkletter doctrine has become "almost as difficuit to follow as the trachs made by a beast of prey in search of its intended victim"). 
of Justice Harlan, however, offered both the possibility of another way and attacks on the transaction-time model that eventually proved irresistible. That his criticisms did not produce an ascendancy of the decision-time model results from two failures to distinguish between model and resultone on the part of the Griffith Court, and one on the part of Justice Harlan himself.

Justice Harlan's recommendations for the treatment of cases on direct review clearly urge the adoption of a decision-time model. ${ }^{252}$ His discussions of such cases never call for "retroactive application" of decisions but simply for application of "the prevailing decisional rule." 253 Transactiontime results, in Justice Harlan's view, may be produced by the law of remedies, ${ }^{254}$ but this question is distinct from the issue of what law to apply. The demand that courts "apply the law as it is at the time, not as it once was," ${ }^{235}$ speaks to the analytical model but does not require any particular result.

When majority support for this analysis on direct review emerged, however, it operated at the level of result. Although Griffith v. Kentucky claims to adopt Justice Harlan's position, its recurrent invocation of "retroactive application "256 marks it quite clearly as a product of the transaction-time model. Moreover, as subsequent cases made clear, ${ }^{257}$ Griffith rejected only selective prospectivity; it did not speak to the possibility of refusing to apply a new rule in the case in which it was announced. The vindication of Justice Harlan's views announced in Griffith was only partial.

Griffith did not itself mark the resurgence of the decision-time model for cases on direct review, but given the persistent conflation of model and result, Griffith's decision-time result pushed towards the decision-time model. Adoption of the Harlan analysis for habeas petitions, on the other hand, offered no support to the decision-time model because Justice Harlan himself had remained within the transaction-time model. Apparently believing that applying decision-time law to habeas petitions would result in "readjudicating convictions according to all legal standards in

252. See, eg, Williams, 401 U.S. at 681 ("I continue to believe that a proper perception of our duties as a court of law . . mandates that we apply the law as it is at the time, not as it once was."); United States y. Estate of Donnelly, 397 U.S. 286, 296 (1970) (Harlan, J., concurring) ("[O]nce the decision to abandon precedent is made, I see no justification for applying principles determined to be wrong, be they constitutional or otherwise, to litigants who are in or may still come to court.").

253. Estate of Donnelly, 397 U.S at 297.

254. See id. at $296-97$

255. Williams, 401 U.S at 681 .

256. See Griffith v. Kentucky, 479 U.S. 314, 316, 318, 322, 328 (1987).

257. See, e.g, James B. Beam Distilling Co. v. Georgia, 501 U.S. 529,538 (1991) 
effect when a habeas petition is filed," ${ }^{258}$ Justice Harlan instead urged the application of transaction-time law. ${ }^{259}$ Noting the desirability of "leaving concluded litigation in a state of repose," he concluded that concerns for finality could defeat the judicial presumption in favor of applying the best current understanding of the law. ${ }^{260}$ When Teague $v$. Lane approved Justice Harlan's reasoning, it understandably did so within a transaction-time model.

Far more puzzling than the transaction-time framework of the Teague Court is Justice Harlan's abandonment of the decision-time model for habeas cases, an unsound and unnecessary step by a great jurist. The position is unsound because finality is unacceptable as a normative justification. The interest in finality is always present, and ordinarily does not overcome a constitutional violation in the conduct of a trial. Because the transaction-time model erases the difference between old and new law, the principle of finality cannot distinguish between habeas petitions relying on new law and ones urging violations of old law. Nor does it satisfactorily distinguish between habeas petitions and cases on direct review, since the States' interests in avoiding disruption and the defendants' interests in application of the new rule are quite similar in both types of cases. ${ }^{261}$

Justice Harlan's invocation of finality is also unnecessary within the decision-time model. On the transaction-time model, a retroactive decision works to change transaction-time law, and thus obviously changes the law applicable to the habeas petitioner as well. The same is not true from the decision-time perspective. The consequence of the decision-time model, as noted above, is that earlier decisions (pegged to their respective dates) are correct. By preserving the correctness of earlier decisions, the decision-time model distinguishes between direct and collateral review in a way that the transaction-time does not.

While neither Griffith nor Teague marked the return of the decisiontime model, their invocations of Harlan and their embrace of decision-time results on direct review showed that the time was ripe for a countercoup. The presence on the Court of conservative Justices, notably Antonin Scalia, who subscribed to the "right answer" model of judicial lawmaking, provided the needed impetus. In American Trucking Ass ins v. Smith, ${ }^{262}$ the two models met head-on. Justice O'Connor, writing for a plurality of four, gave a clear statement of the transaction-time approach. ${ }^{263}$ Invoking Chev-

\footnotetext{
258. Williams, 401 U.S. at 683 .

259. See id.

260. See id.

261. See supra note 188.

262. 496 U.S. 167 (1990).

263. See id at 171-200
} 
ron Oil, in what was to be its last appearance in an opinion of the Court, she urged the limitation of Griffith to the criminal context and concluded that the Scheiner decision should not be applied retroactively. ${ }^{264}$

The dissent, by contrast, offered an analysis rooted in the decisiontime model. Also writing for four Justices, Justice Stevens argued that "adherence to legal principle requires that we determine the rights of litigants in accordance with our best current understanding of the law."2.65 Quoting Justice Harlan's concurrence in Estate of Donnelly, he concluded that "while there is flexibility in the law of remedies, this does not affect the underlying substantive principle that short of a bar of res judicata or statute of limitations, courts should apply the prevailing decisional rule to the cases before them.'

Justice Scalia provided the necessary fifth vote for transaction-time result. But, much like the Gelpcke Court, he did so from a Blackstonian perspective, admitting the authority of the earlier decision but denying its correctness. Thus while five members of the Court were willing to reach the transaction-time result, five were also clearly lined up behind the decision-time model. Subsequent cases showed, however, that the Justices did not view the issue with the clarity in which Smith had presented it,

Two cases handed down on the same day in 1991, James B. Beam Distilling Co. v. Georgia ${ }^{267}$ and Lampf, Pleva, Lipkind, Prupis \& Petigrow $v$. Gilbertson, ${ }^{268}$ highlighted the tension within the Court. The fivemember Lampf majority applied decision-time law with no mention of retroactivity - an opinion clearly within the decision-time model. ${ }^{269}$ In James Beam, by contrast, the Court reached a decision-time result via retroactive application of the new rule. ${ }^{370}$ The two-Justice plurality, along with one concurring Justice and the three dissenters, employed the transaction-time model. ${ }^{271}$ Only the three-Justice concurrence, composed of

\footnotetext{
264. See id at 178-79.

265. Id. at 214 (Stevens, J dissenting).

266. Id at 215 (quoting United States v. Estate of Donnelly, 397 U.S. 286, 297 (1970) (Harlan. J.. concurring)).

267. 501 U.S. $529(1991)$

268. 501 U.S. $350(1991)$.

269. See id. at $35 \mathrm{i}$.

270. See Beam, 501 US, at 544

271. See id at 532. Justice O'Connor, in dissent, attempted the Gelpcke/Smith maneuver of refusing retroactive effect to decisions believed wrong and argued that although Bacchus Imports Lid. v. Dias, 468 U.S. 263 (1984), had applied its rule to the parties before the Court, stare decisis did not compel her to retroactive application of the rule in Beam. See id. at $550-52$ (O'Connor, J., dissenting). Within the decision-time nodel, this move is legitimate. Because the decision-time result in Scheiner changes the law only after that decision, the tax at issue in Smith was constitutional until Scheiner was handed down. Justice O'Connor. however, is a consistent proponent of the transaction-time model. On this mode of analysis. the earlier decision-time result in Bacchus asserts
} 
Justices Scalia, Marshall, and Blackmun, advocated the decision-time model.

With the resignation of Justice Brennan, Justice Scalia lost a staunch, if unlikely, decision-time ally. The latest changes in the Court have removed two more, Justices Marshall and Blackmun, ${ }^{272}$ and while the new additions have supported decision-time results, the decision-time model seems again on the wane. The most recent cases, Harper v. Virginia Department of Taxation ${ }^{273}$ and Reynoldsville Casket Co. v. Hyde, ${ }^{274}$ have reached decision-time results but have done so, like James Beam, within a transaction-time model. Both cases framed the question as one of "retroactive effect," and both held that application of a new rule in the case announcing it implies that the rule is retroactive. ${ }^{275}$ Only Justice Scalia, concurring in Harper, argued for the decision-time model. ${ }^{276}$

Like the Warren Court, the current Court tends towards the transaction-time model. Unlike its predecessor, however, it does so with an awareness of the model's limitations, disayowing the incoherence of selective prospectivity. Pure prospectivity, though still mentioned as permissible, seems unlikely to reemerge. Not only does a strong majority seem to favor decision-time results, but even the prospectivity proponents are reluctant not to apply a new rule in the case announcing it, because of the advisory opinion problem. ${ }^{277}$ Justices O'Connor and Kennedy, the champions of prospectivity, thus find themselves in an unenviable double bind. Avoiding advisory opinions requires them to urge retroactive application in the first case, but once this has been granted, the consistent majority opposition to selective prospectivity requires retroactive application thereafter. In terms of reaching transaction-time results via prospectivity, their tools are not equal to their task.

A glance at the academic reviews of the Court's performance reveals that it is not a hit. ${ }^{278}$ The lukewarm reception is justified; the caselaw is an uninspiring hodgepodge of two- and three-Justice opinions. It could be much better, and employing the decision-time model would make it so, as

not only what the law is, but what it was at the time of the transaction. Its stare decisis effect, then. extends retroactively all the way back to the transaction.

272. Both Justice Brennan and Justice Blackmun were late converts to the decision-time model. Until United States v. Johnsan, 457 U.S. 537 (1982), both Justices had taken positions inconsistent with Justice Harlan's approach on direct review. See, e.g. Williarns v. United States, 401 U.S. 646 (1971): Desist v, United States, 394 U.S. 244 (1969).

273. 509 U.S. 86 (1993).

274. 514 U.S. 749 (1995)

275, See Harper, 509 U.S at 90; Reynoldsville Casket, 514 U.S. at 758 .

276. See Harper, 509 U.S at 102-10 (Scalia, J, concurring).

277. See Goodman v. Lukens Steel Co., 482 U.S. 656. 689-90 (1987) (O'Connor, J., concurring).

278. See sources cited supra notes 166-67. 
the following section demonstrates.

\section{Using the Decision-Time Model}

\section{a. Criminal Procedure}

Within the decision-time model, the concept of retroactivity has no role to play. The result of adopting this model in the criminal procedure context would thus be the application of new rules to all cases on direct review, consistent with the traditional judicial duty to resolve cases according to the best current understanding of the law. ${ }^{279}$ Cases on collateral review, by contrast, would be analyzed according to the law prevailing at the time of the original trial. The decision-time model thus produces results very similar to those of the current Griffith/Teague regime, with substantially greater doctrinal coherence.

Prospective results would be reached through the law of remedies. The remedial flexibility of reviewing courts in the area of criminal procedure is not entirely clear, and a pre-Warren Court might have been justifiably hesitant to rely on the law of remedies to mitigate the disruptive effect of new constitutional rules. Until the 1960 s, it was generally assumed "that constitutional violations could never be regarded as harmless error." 180 The ability to reach transaction-time results on direct review of criminal appeals was thus severely constrained in precisely the area of the Court's great criminal procedure innovations. However, in part perhaps because of those innovations, the Warren Court also reworked the harmless error doctrine. In 1963, four Justices in Fahy v. Connecticut ${ }^{281}$ had indicated a disposition to hold that erroneous admission of unconstitutionally obtained evidence could be deemed harmless on appeal. Four years later, Chapman v. Californi ${ }^{18 z}$ explicitly recognized the possibility of harmless constitutional error.

Both Fahy and Chapman are, from one perspective, retroactivity cases, in that the "errors" in both were produced by decisions intervening between trial and appellate review. ${ }^{283}$ Neither, however, features an explicit discussion of retroactivity; the effect of the rule is determined entirely by remedial doctrines. Harmless error analysis, of course, is not entirely satisfactory in that it makes no inquiry into the purpose of the rule.

279. See generally Note, supra note 225 (urging the application of decision-time law and the use of remedial flexibility in the limited context of exclusionary rule decisions on direct review).

280. YaLe Kamisaret AL, MODERN CRIMINAL PROCEDURE 1605 (8th ed, 1994).

281. 375 U.S $85(1963)$

282. 386 U.S. 18 (1967)

283. Intervening in Chapman was Griffin v. California, 380 U.S. 609. 613-15 (1965), which held unconstitutional prosecutorial comment on a defendant's failure to testify. Mapp v Ohio. 367 US 643 (1961), the case at issue in Linkleter. intervened between trial and appellate revicw in Faty. 
It is thus at best a somewhat unprincipled stop-gap measure.

A purpose-based analysis would have a reach both broader and more discerning. Where the purpose of a new rule is deterrent, as the Court's Fourth Amendment innovations have been, an individual defendant has little grounds on which to complain if the exclusionary remedy is withheld in his case. Given that the exclusionary rule is a judicially created remedy rather than a substantive individual right, reviewing courts should have some latitude in withholding it where new rules are at issue. Rules creating procedural rights that do belong to defendants, rather than to society, would by contrast demand remedies on direct review. ${ }^{284}$

The danger posed by a purpose-based analysis is that a predictable remedial regime under which, for example, the exclusionary remedy was withheld for new Fourth Amendment rules, would give litigants little incentive to raise novel claims. The result might be a dramatic decrease in the pace of constitutional change. Selective prospectivity-rewarding only the litigant in whose case a new rule is announced-has been suggested as the best way to preserve litigant incentives while minimizing the disruption of state criminal justice systems. ${ }^{285}$

Selective prospectivity, however, is impossible to reconcile with courts' commitment to do justice to litigants on the merits of their individual cases. Nor, I think, is it really necessary to prevent constitutional ossification. A purpose-based inquiry, recall, would withhold a remedy only where the new rule is a clear break with existing doctrine. If the new rule has any basis in constitutional law, it can presumably also be reached incrementally. Finally, the concern about litigants' incentives is minimized by any remedial calculus that is not perfectly predictable. Since no clear line exists between incremental changes in law and rules so new that their enforcement would serve no deterrent purpose, the result of a purposebased inquiry should seldom be foreordained. Moreover, the extent to which the Fourth Amendment deters questionable police conduct is a function of how willing courts are to apply new rules. The degree of deterrence desired is a fact-sensitive question that could well be influenced by the circumstances of an individual case. If uncertainty as to whether a remedy will be granted exists, and if arguments can be made on either side, litigants can be expected to press novel claims as vigorously as ever.

A purpose-based remedial inquiry, used within the decision-time model, would allow courts to do justice to litigants on the merits of their claims. It would permit prospective application of some new rules without

234. An example of this sort of right is the right to counsel recognized by Gideon v: Wamuright, 372 U.S. 335 (1963)

285. See, e.g. Fallon \& Melizer, supra note 42, at 1811-12. 
selectively warping the substantive law around lucky individuals, and it would preserve litigants' incentives to pursue novel claims. While the post-Griffith Court seems to have little interest in reaching prospective results in criminal cases on direct review, the possibility exists.

\section{b. Statutes of Limitations}

Decisions applying new statutes of limitations offer one of the clearer cases for purpose-based analysis. Lampf, for example, featured a situation in which lower courts had regularly borrowed state statutes of limitations to govern the federal right of action implied under Rule 10b-5. The Court decided that a uniform federal statute of limitations would better serve justice by promoting uniformity and predictability. ${ }^{280}$. This reasoning is quite convincing; what is harder to see is how the purposes of uniformity and predictability are served by applying the new federal statute of limitations to cases pending on direct review. The Lampf Court notably passed over this issue without discussion, provoking both a sharp dissent and an unsuccessful attempt by Congress to undo the inequitable results.

The decision-time model, which the Lampf Court adopted, in no way compels this decision-time result. The doctrine of equitable tolling is regularly applied to protect parties whose claims have lapsed through no fault of their own, ${ }^{287}$ and could easily have been applied in Lampf. ${ }^{288}$ But Lampf's rejection of equitable tolling was echoed by Reynoldsville Casket. That case featured an Ohio state tolling statute that "in effect, gave Ohio tort plaintiffs unlimited time to sue out-of-state (but not in-state) defendants." ${ }^{239}$ The Court held the statute unconstitutional in Bendix Autolite Corp. v. Midwesco Enterprises, Inc., ${ }^{290}$ and the question in Reynoldsville Casket was the retroactive effect of Bendix. Because the Bendix Court had applied its rule to the parties before it, Harper demanded that it be applied also to the Reynoldsville Casket plaintiff.

\footnotetext{
286. See Lampf, Pleva, Lipkind, Prupis \& Petigrow v Gilbertson, 501 U.S. 350. 357 (1991).

287. Usually. equitable tolling is invoked where the injury has not been discovered it is but a small stretch to apply this to situations in which the injured party has relied on authoritative judicial statements of a statute of limitations.

288. The Lampf plaintiffs raised the equitable tolling argument, and the Cour rejected it, based on what it termed "the inescapable conclusion that Congress did not intend equitable tolling to apply in actions under the securities laws." Lampf, 501 U.S. at 363. This may well be correct as a matter of congressional intent with respect to securities actions generally. The result of its application in Lampf, however, was so disturbing to Congress that it enacted only partly constitutional legistation in an only partly successful attempt to reverse the decision. See Plaut v. Spendthrift Farm, Inc, 514 U.S 211,225 (1995) (concluding that the legislation violated the separation of powers becatise it instructed federal courts to reopen final judgments). Given the congressional response, equitable tolling seems fairly consonant with what Congress would have intended on the facts of Lampf.

289. Reynoldsville Casket Co. v. Hyde, 514 U.S. 749, 750 (1995).

290. 486 U.S. $888.894-95$ (1988).
} 
The plaintiff tried to avoid this result by arguing that the Ohio courts might continue to toll the statute of limitations "as a state law "equitable" device." ${ }^{291}$ The Court rejected the invitation, stating that "we do not see how ... the Ohio Supreme Court could change a legal outcome that federal law, applicable under the Supremacy Clause, would otherwise dictate simply by calling its refusal to apply that federal law an effort to create a remedy. ${ }^{2{ }^{292}}$ The significance of Reynoldsville Casket is not entirely clear. Given that it relied on the application of Bendix to the Bendix parties, it is still possible to maintain that a court may consider equitable factors in granting remedies in the first case applying a new rule and be consistent thereafter. Thus Reynoldsville Casket may merely extend to remedies the Beam Court's statement that "the substantive law will not shift and spring " ${ }^{293}$ on the basis of individual equities. ${ }^{294}$

On this reading, the Court demanded no more than consistency with Bendix, ${ }^{295}$ and Bendix is intelligible on a purpose-based remedial analysis. The Ohio tolling provision at issue in Bendix and Reynoldsville Casket was struck down not in order to promote uniformity and predictability, but rather to prevent discrimination against out-of-state defendants. The purpose of preventing discrimination was quite clearly served by reaching a decision-time result, and it might even have required the Court to reject an attempt by the Ohio court to invoke equitable tolling. ${ }^{296}$ Use of equitable tolling to reach prospective results in cases applying new statutes of limitations is consistent with the decision-time model, the Court's precedents, and considerations of substantive justice.

\section{c. Tax Refunds}

Cases seeking refunds of unconstitutionally collected taxes provide perhaps the most tempting case for the transaction-time model. Where the conduct complained of is ongoing, as is the case with tax collection, the transaction-time model allows for purely prospective relief without facing the advisory opinion problem. This approach, however, would come into

\footnotetext{
291. Reynoldsville Casket, 514 U.S, at 753 .

292. Id.

293. James B. Beam Distilling Co v Georgia, 501 U.S. 529, 543 (1991)

294. What makes this reading of Reynoldsville Casket a little difficult is the statement that federal law, i.e., the unconstitutionality of the tolling statute, dictates the result. It is not clear why the remedial inquiry is not a state law question: why the Ohio courts could not equitably toll the otherwise applicable Ohio statute of limitations as a matter of state remedial law. The Reynoldswile Casket opinion suggests that remedial discretion cannot be used to reach transaction-time results, and thus seems to abandon Beam's distinction between the "remedial" and the "choice-of-law" inquiries.

295. The retroactivity issue in Bendix was raised for the first time on appeal, and the Court refused to consider it. Apparently as a consequence, it applied the decision retroactively.

296. This issue was not clearly presented, as the Ohio coun characterized its disposition as refusing retroactive effect. See Hyde v. Reynoldsville Casket Co.. 626 N.E.2d 75. 77 (Ohio 1994).
} 
immediate conflict with Griffith ${ }^{297}$ If a state pursued both a civil and a criminal action against resisting taxpayers and both cases reached the Court on direct review, a civil holding of non-retroactivity, coupled with Griffith's required criminal retroactivity, would produce conflicting statements about the constitutionality of the tax.

This conflict could be avoided if Griffith's decision-time results were reached within a decision-time model, ${ }^{298}$ and consistency could be produced by a regime that called for the transaction-time model in civil cases but the decision-time model in criminal ones. This dichotomy, at the level of result, was urged by Justice O'Connor in Smith, ${ }^{299}$ and rejected over her dissent in Harper ${ }^{300}$ The distinction is no easier to justify in terms of conceptual models. Although distinguishing between criminal and civil cases would allow the Court somewhat greater freedom in civil cases featuring ongoing conduct, it is too unprincipled to be very attractive.

Although it is ultimately undesirable, the transaction-time model is made more appealing by the difficulty in reaching prospective results via remedial analysis in tax refund cases. The costs to states of refunding unconstitutional taxes can be immense, and courts may understandably want to avoid imposing crushing refund liability. ${ }^{301}$ Of course, a mere finding of unconstitutionality does not mandate refunds. In some circumstances, taxes may be retroactively altered by the state to render them constitutional; this is often the case with taxes that violate the Equal Protection Clause or the dormant Commerce Clause ${ }^{302}$ Additionally, the availability of a predeprivation hearing may allow states to avoid refunds, ${ }^{303}$ The question is whether prospective results may be reached where no predeprivation hearing was available and no retroactive reformation is possible. The purpose-oriented analysis suggests not; since the reasons behind the unconstitutionality of a tax will ordinarily be applicable to the individual taxpayers, it seems that no remedial adjustment should be made.

In support of this position, it might be argued that states that unconstitutionally collect taxes without affording taxpayers an opportunity to

297. This point and a more extended exposition of the following example have been nicely made by Fallon and Melizer. See Fallon \& Meltzer, supra note 42, at 1767-68.

293. On the decision-rime model, the constitutionality of the tax in the past would not affect the result on direct review. Nor would it on collateral review, since a decision-time court would grant a habeas petition to a person imprisoned for constitutionally protected conduct. If the prospective decision was not constitutionally grounded, a habeas petitioner would get no relief, but this result is not inconsistent with prospective invalidation

299. See American Trucking Ass'ns v. Smith, 496 U.S, 167. $197-99$ (1990).

300. See Harper v. Virginia Dep't of Taxation, 509 U.S. 86, 97 (1993)

301. See id at 129-30 (O'Connor, 1., dissenting).

302. See id at 100-01.

303. See id 
challenge their legitimacy deserve no special solicitude. This argument may be too strong, since an unpredictable Supreme Court decision has the potential to inflict massive liability on a state acting in good faith. The problem, however, is a result of the anomalous treatment of tax refund suits, rather than a retroactivity issue.

The doctrine of sovereign immunity generally frees states from the obligation to pay compensatory damages for past injuries. The normative rationale for the different treatment of tax refunds is hard to uncover, especially since it seems to favor property over life and liberty in the constitutional calculus. ${ }^{304}$ Regardless of the explanation, the solution to the problem of state liability for unconstitutionally collected taxes should be sought in immunity doctrines rather than by a deformation of retroactivity jurisprudence ${ }^{305}$ It might be reasonable, for example, for the Court to create a qualified immunity to tax refund suits similar to that enjoyed by state officials against Section 1983 damages actions for constitutional violations. $^{306}$

\section{CONCLUSION}

The formulation of a theoretically justifiable approach to retroactivity must start with a reformation of the underlying conceptual framework. The Warren Court's adoption of the transaction-time model marked an unfortunate turn into doctrinal confusion and incoherence; the current Court has undertaken repairs at the level of result and has consequently

304. The positive rationale is only somewhat clearer. Ward $v$ Love County, 253 U.S. 17, 24 (1920), rests its refund requirement on the principle that "money got through imposition may be recovered back," and derives this principle in tum from the Takings Clause. The Takings Clause cannot be the whole story, however, since no refund of an unconstitutional tax is required if the state provides an opportunity for a predeprivation hearing. See Mchesson Corp. v. Division of Alcoholic Beverages \& Tobacco, 496 U.S. 18, 36-37 (1990). Monies collected under an unconstitutional tax would still seem to be private property taken for public use, and the Takings Clause makes no exception for takings with due process. Where no predeprivation hearing is available, the refund requirement is currently characterized as flowing from the Due Process Clause. See id. at 31 .

305. Interestingly, Scheiner offered the possibility of pure prospectivity by remand to the state court for resolution of the retroactivity question. See American Trucking Ass ins v Scheiner, 483 U.S. $266,297-98$ (1987). State courts are often not prohibited from issuing advisory opinions and might favor state tax authorities over out-of-state plaintiffs. On remand, the Pennsylvania Supreme Court. for example, held the Scheiner decision purely prospective. See American Trucking Ass'ns v. McNulty. 596 A.2d 784, 790 (Pa. 1991). However, the retroactivity of a determination of unconstitutionality is a federal question, as the Smith Court held. See American Trucking Ass'ns v. Smith, 496 U.S 167.177 (1990). The ability of a state court on remand to adjust remedies to blunt the effect of a federal holding of retroactivity has been cast in serious doubt by Reynoldsville Casket

306. This would require a change in Takings Clause jurisprudence, since First English Evangelical Lutheran Churcin v County of Los Angeles. 482 U.S 304. 316 n.9 (1987), rejected the argument that sovereign immunity can bar a monetary remedy under the Just Compensation Clause 
been only partially successful. The decision-time model, advocated by Justice Harlan and displayed in the pre-Warren Court jurisprudence, would allow the Court to reach its currently preferred results with greater theoretical consistency.

Choice of analytical model does not determine results. While adoption of the decision-time model would bring a theoretical coherence, it would not uniformly require decision-time results. The existing doctrines of remedial discretion, including harmless error and equitable tolling, would allow courts to reach just results in the cases before them without deforming retroactivity jurisprudence to suit remedial preferences. In areas where remedial discretion does not provide sufficient flexibility, as may be the case with tax refund suits, the answer must be sought in the substantive law of those particular areas.

Most importantly, the decision-time model makes the distinction between direct and collateral review that has been so elusive. Abandoning the transaction-time model will free the Court from the impossible task of trying to justify results that cannot be justified within its theoretical framework; it will solve the problem of retroactivity. On this foundation, a coherent jurisprudence may be built. 